\title{
28
}

\section{Integrative Analysis Applying the Delta Dynamic Integrated Emulator Model in South-West Coastal Bangladesh}

\author{
Attila N. Lázár, Andres Payo, Helen Adams, \\ Ali Ahmed, Andrew Allan, Abdur Razzaque Akanda, \\ Fiifi Amoako Johnson, Emily J. Barbour, Sujit \\ Kumar Biswas, John Caesar, Alexander Chapman, \\ Derek Clarke, Jose A. Fernandes, Anisul Haque, \\ Mostafa A. R. Hossain, Alistair Hunt, \\ Craig W. Hutton, Susan Kay, Anirban Mukhopadhyay, \\ Robert J. Nicholls, Abul Fazal M. Saleh, \\ Mashfiqus Salehin, Sylvia Szabo, \\ and Paul G. Whitehead
}

\subsection{Introduction}

The research described in this book had a vision from its inception of developing a regional integrated assessment model to explore the future of coastal Bangladesh in terms of ecosystem services and human wellbeing. This requires a systematic framework which brings together all the individual components described in previous chapters, recognising and

\footnotetext{
A. N. Lázár $(\bowtie) \bullet A$. Chapman • D. Clarke • R. J. Nicholls Faculty of Engineering and the Environment and Tyndall Centre for Climate Change Research, University of Southampton, Southampton, UK
} 
capturing important cause-effect associations and processes and their relative importance. Integrative assessment enables an analysis of a whole system, promoting the understanding of the importance of individual elements and providing insights into the future across a range of plausible scenarios. Such information enables science and policy processes to better understand current drivers and plausible development trajectories and consider how to steer that development towards favoured future states. In this way, the scientific endeavours described in this book can inform policy.

Achieving a successful, integrated representation of the delta system is highly reliant on the relationship between the integrated modellers and the rest of the project team. A frequent exchange of knowledge and ideas between team members is essential to ensure that system linkages, inputs and outputs are appropriately structured and agreed. This is a challenging

\section{A. Payo}

British Geological Survey, Keyworth, Nottingham, UK

H. Adams

Department of Geography, King's College London, London, UK

A. Ahmed

Climate Change and Health, International Center for Diarrheal Disease Research, Bangladesh (icddr,b), Dhaka, Bangladesh

\section{A. Allan}

School of Law, University of Dundee, Dundee, UK
A. R. Akanda • S. K. Biswas

Irrigation and Water Management Institute, Bangladesh Agricultural Research Institute, Gazipur, Bangladesh

F. Amoako Johnson

Social Statistics and Demography, Faculty of Social, Human and Mathematical Sciences, University of Southampton, Southampton, UK

E. J. Barbour • P. G. Whitehead

School of Geography and the Environment, University of Oxford, Oxford, UK 
and time-consuming process. Researchers need to think about strategic relationships, accounting for factors outside of their specialist areas (domain), evaluating consequences of any changes and fully exchanging ideas with other disciplines. The interaction between the specialists and integrators needs to be iterative not only because the integration method needs to be in line with theories, methods and results of the domain in question but also because the discussions and multiple model representations might prompt domain experts to re-evaluate systems descriptions or do additional analysis. The integrative modellers (or integrators) often need (i) to develop new methods to represent complex, computationally intensive models in a 'rapid' assessment frameworks (i.e. using statistical emulators), (ii) to fill the gaps in the conceptual model by developing new or further developing existing models and (iii) to harmonise scales

\section{J. Caesar}

Met Office Hadley Centre for Climate Science and Services, Exeter, Devon, UK J. A. Fernandes $\bullet$ S. Kay

Plymouth Marine Laboratory, Plymouth, UK

A. Haque • A. F. M. Saleh • M. Salehin

Institute of Water and Flood Management, Bangladesh University of Engineering and Technology, Dhaka, Bangladesh

M. A. R. Hossain

Department of Fisheries Biology and Genetics, Bangladesh Agricultural University, Mymensingh, Bangladesh

A. Hunt

Department of Economics, University of Bath, Bath, UK

C. W. Hutton

Geodata Institute, Geography and Environment, University of Southampton, Southampton, UK

A. Mukhopadhyay

School of Oceanographic Studies, Jadavpur University, Kolkata, India

S. Szabo

Department of Development and Sustainability, Asian Institute of Technology, Bangkok, Thailand 


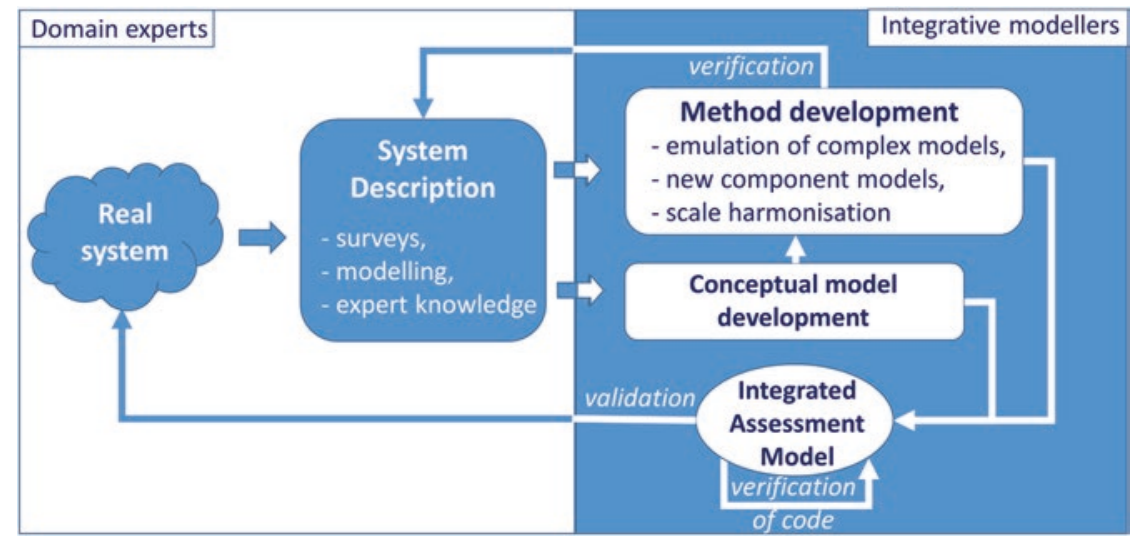

Fig. 28.1 Generic model development process. Domain experts provide the detailed understanding of the system, whereas the integrated modeller(s) develop the methods and create the model environment. The interaction is iterative and results in a more robust system understanding

and units so the components can 'talk' to each other during the model runs. Finally, the integrators always need to ensure that the integrated assessment model is robust and reliable by continuously testing, validating and evaluating the code, the methods and emerging results together in partnership with the domain experts. Ultimately, the process (Fig. 28.1) results in a robust and representative view of the relevant overall system and the consequences of change, as well as generating a highly cohesive research team who share a common understanding expressed in the model framework.

To achieve the aims of this research (i.e. assessment of future environmental change and policy responses relevant to ecosystem services and poverty alleviation in deltas), the quantitative framework combines a variety of approaches in a meta-model to describe the system as simply and efficiently as possible. This flexible model structure is designed to be able to incorporate any type of data, method or other information generated within the project. The strong collaboration with individual specialists ensures the careful selection of model elements and appropriate methods, data and system behaviour. The following sections describe 
this meta-model, which is called the 'Delta Dynamic Integrated Emulator Model $(\triangle \mathrm{DIEM})$ ' including the development process, the model elements and illustrative outputs. Validation, testing of the model and the model inputs are described in Appendices 1 and 2 of this chapter.

\subsection{Building the Delta Dynamic Integrated Emulator Model ( $\Delta$ DIEM)}

Understanding the system of coastal Bangladesh (Fig. 28.2) is an essential initial step in building the $\triangle$ DIEM model. Building upon this system understanding, the skillset requirement and the necessary model elements are identified (Fig. 28.3). Additionally, the types of data required to fulfil

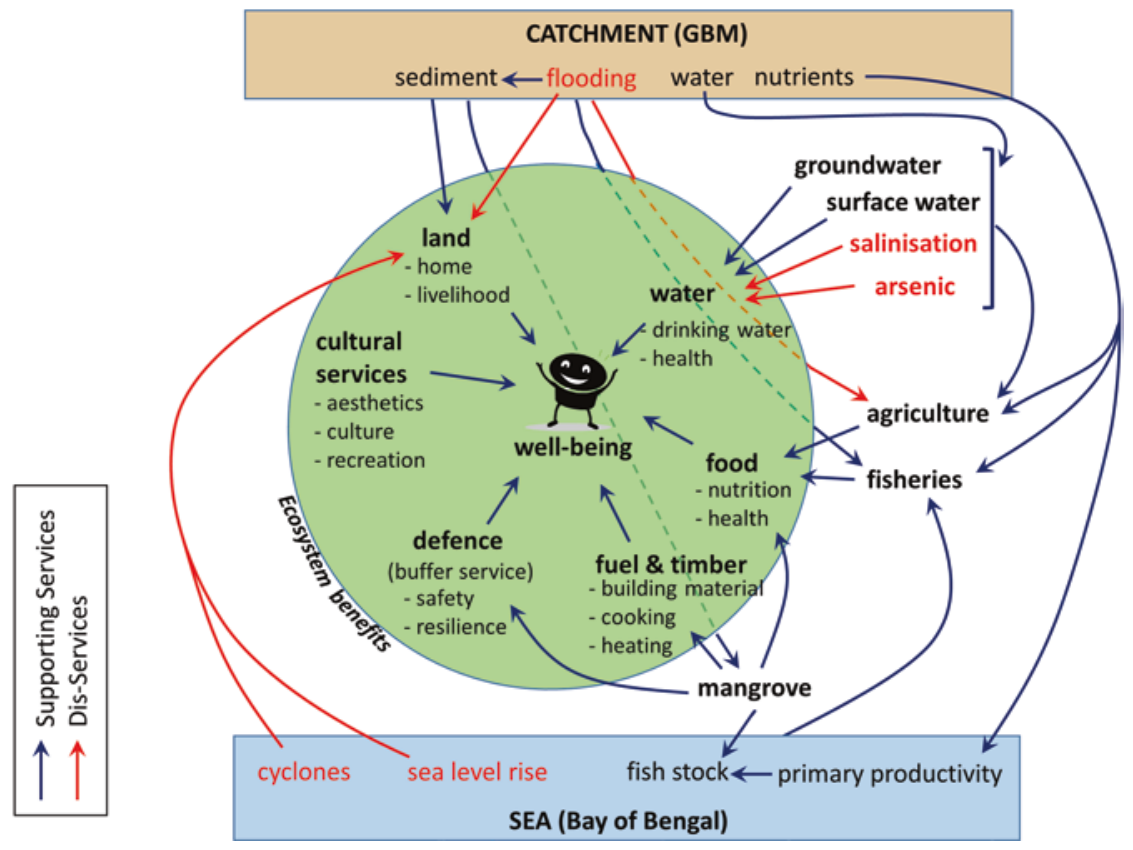

Fig. 28.2 Conceptual map of ecosystem services and disservices within the project domain 


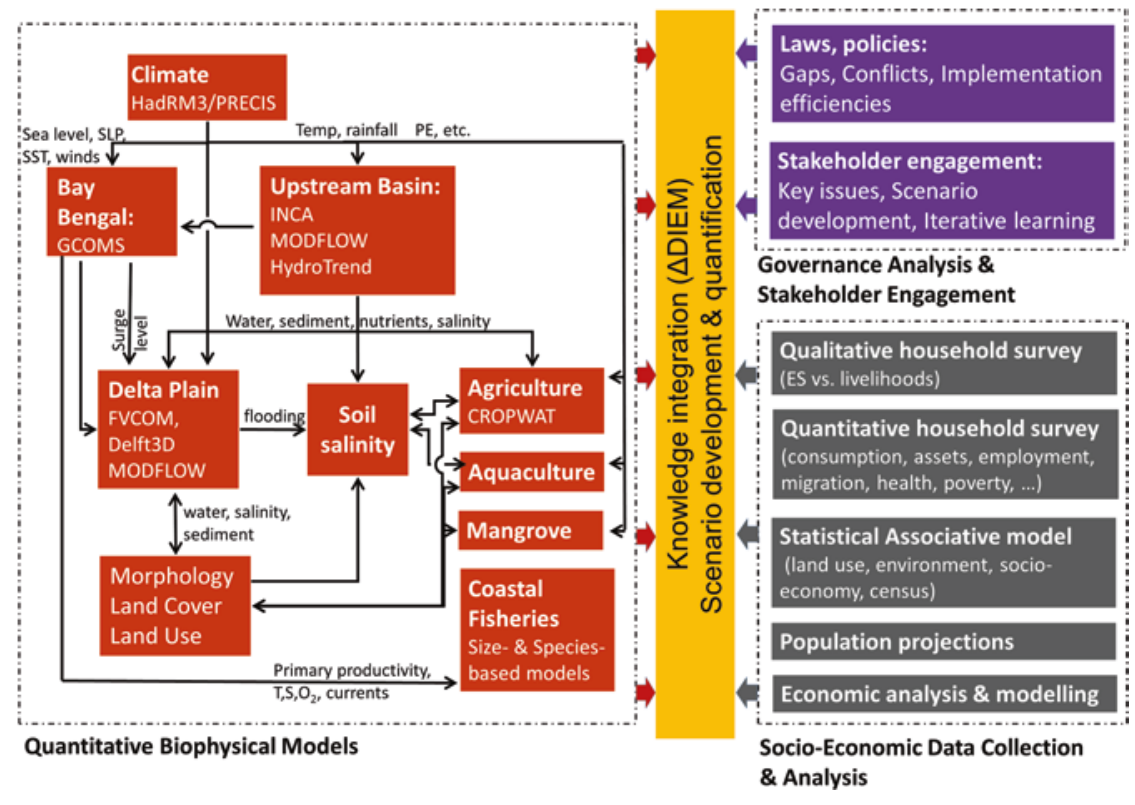

Fig. 28.3 Building on Fig. 28.2, formalised relationships between components of the research

the component models to be integrated as well as the geographical extent of the model (boundaries and external factors) are determined. This process helps to identify any gaps in understanding and/or data/information.

This project mapping exercise illuminates the spatial and temporal scales of the planned analysis. It is clear that disciplines work with different spatial and temporal units. For example, the quantitative bio-physical models are linked for the entire transboundary system with mostly daily/ sub-daily calculation routines (except the fisheries and mangrove models that have annual and decadal time steps, respectively). The governance analysis, however, focuses on Bangladesh with no explicit temporal scale, while the socio-economic data collection and analysis focuses on the south-west coastal zone of Bangladesh with multiple spatial (households, Union Parishad, districts, coastal zone) and temporal (seasonal/annual/ 
five-yearly) scales. To incorporate these multiple scales while keeping the integrated model as efficient as possible with dynamic calculations, the unit of analysis is at the Union Parishad scale and focusses on the southwest coastal zone of Bangladesh. Union Parishads (from now on, called Union) are the smallest planning units of Bangladesh consisting of a few villages and with an average surface area of $26 \mathrm{~km}^{2}$ and a population of around 20,000 people. To capture seasonality, the temporal scale of $\triangle \mathrm{DIEM}$ is set as daily for the bio-physical components and monthly for the household-related components.

\subsubsection{The Delta Dynamic Integrated Emulator Model $(\triangle \mathrm{DIEM})$}

$\triangle$ DIEM strongly builds on the frameworks shown in Figs. 28.2 and 28.3. The integrated model (Fig. 28.4) is readily defined into four distinct components: (i) the boundary conditions, (ii) the biophysical calculations, (iii) the process-based household well-being calculations and (iv) the statistical associative well-being calculations.

\subsubsection{Boundary Conditions}

The 'BoundaryConditions' class summarises all input types that $\triangle$ DIEM uses. These inputs are the national scenarios (e.g. economics; see Chap. 12), transnational (climate and river flows; see Chaps. 11 and 13 (also Whitehead et al. 2015; Caesar et al. 2015)) and regional (Bay of Bengal sea elevation and fisheries; see Chaps. 14 and 25 (also Fernandes et al. 2016; Kay et al. 2015)) generated for the 1981-2099 period. These inputs are used as lookup tables in $\triangle \mathrm{DIEM}$ selecting the appropriate time series for each scenario run. There are three exceptions: (i) the population projections which allow the user to change the assumptions of the cohort component population projection method (see Chap. 19 and Szabo et al. 2015), (ii) the Farakka Treaty values (Farakka Treaty 1996) can be adjusted to test plausible governance interventions and (iii) the future economic assumptions can also be 


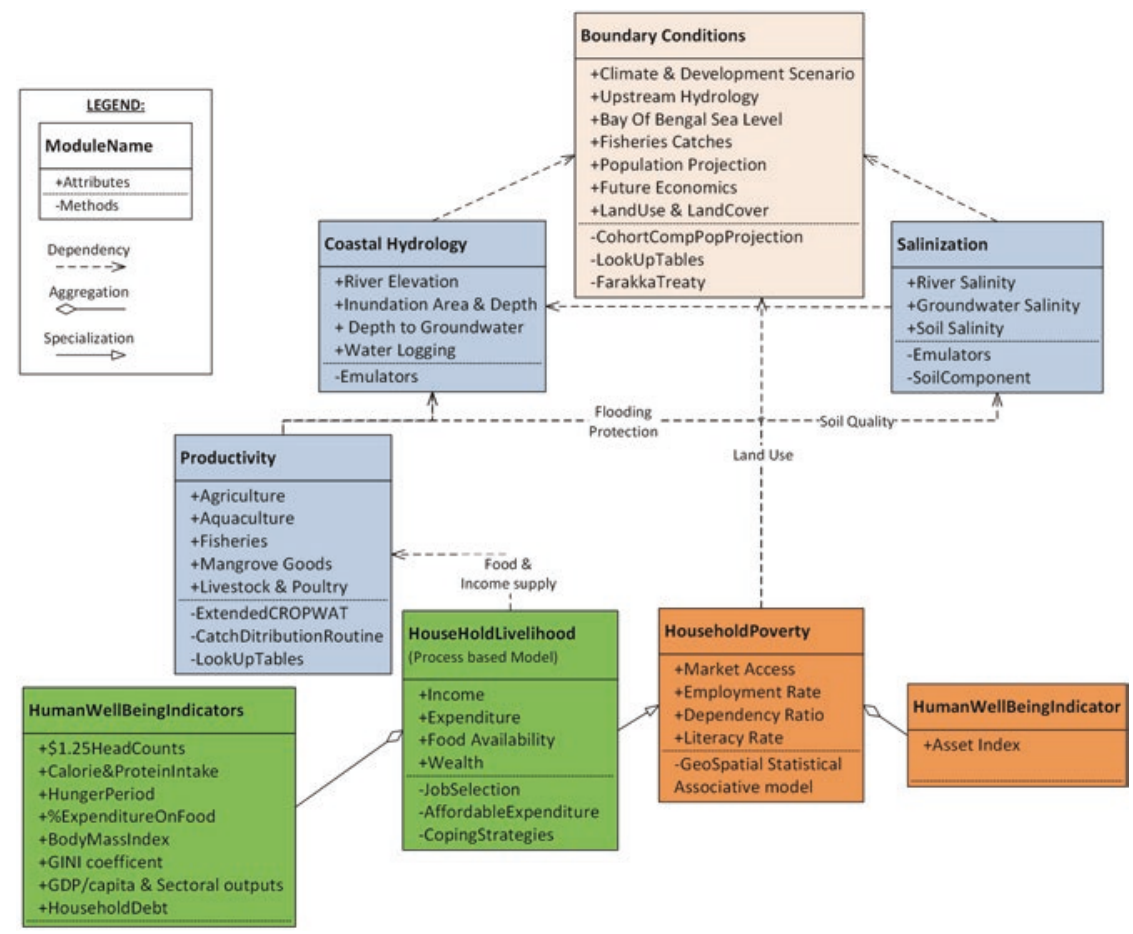

Fig. 28.4 Final conceptual model of $\triangle$ DIEM using standard Unified Modelling Language conventions. Colours highlight the four distinct components of $\triangle$ DIEM: (1) the boundary conditions (pink), (2) the bio-physical calculations (blue), (3) the process-based household well-being calculations (green) and (4) the statistical associative well-being calculations (brown)

modified by the user. In the future, any of the look-up tables can be replaced or extended by a direct link to the source model.

\subsubsection{Bio-physical Calculations}

The bio-physical calculations include the 'Coastal Hydrology', 'Salinisation' and 'Productivity' classes in Fig. 28.4. These calculations have a daily time step and are carried out on all 653 Unions of the study area. 
Coastal hydrology is captured using linear statistical emulators. These distil the full hydrological model outputs (Delft-3D, FVCOM, MODFLOW-SEAWAT) to their core elements (see Payo et al. 2017). Using the Partial Least Square (PLS) regression method, linear emulators of river elevation and salinity are generated for 105 selected river locations and groundwater depth and salinity for each one of the 653 Unions. PLS regression is a technique that combines Principal Component Analysis (PCA) with multiple linear regression (Clark 1975) to predict a set of dependent variables from a set of independent variables or predictors. PLS regression is particularly useful when the prediction of a set of dependent variables from a (very) large set of independent variables (i.e. predictors) is needed. The PCA provides a preprocessing technique to reduce the dimensions of the inputs and outputs, thus making the calculations significantly faster and capturing the spatial autocorrelation simultaneously. The processing time required to emulate all the hydrological variables for all 653 Unions for a 50-year simulation is approximately one minute on a four-core computer (2.70GHz processor, 16GB RAM, 64-bit Win7 operation system). When this one-minute runtime is compared, for example, with the 48 hours Delft-3D computation time of one year for the same area (on an Intel Core i7 processor computer), the benefit of using emulators becomes clear. Inundation area, inundation depth and waterlogging are calculated for: (i) each Union for land behind existing embankments (i.e. protected land) and (ii) the remaining land that is being considered non-protected.

Farming is the dominant ecosystem service-based livelihood in coastal Bangladesh. Thus, the farming component needs to be comprehensive to allow investigation of detailed land use and farm management practices such as new crop varieties, cropping patterns, irrigation water source scenarios and so on. Hence, $\triangle$ DIEM utilises the extended CROPWAT model (see Chap. 24 and Lázár et al. 2015) which considers traditional agriculture and pond-based aquaculture together and is fully coupled with a water and soil water balance calculation (Payo et al. 2017). The soil and crop productivity component of $\triangle$ DIEM (Fig. 28.5) therefore integrates climate data, the emulated coastal hydrology, crop characteristics (cropping pattern calendar and area cover, crop type, rooting depth and crop coefficient), soil characteristics (soil type, structure and porosity) and ground elevation (Union-specific hypsometric curves). Daily water and salt fluxes due to river and coastal flooding, capillary rise and 

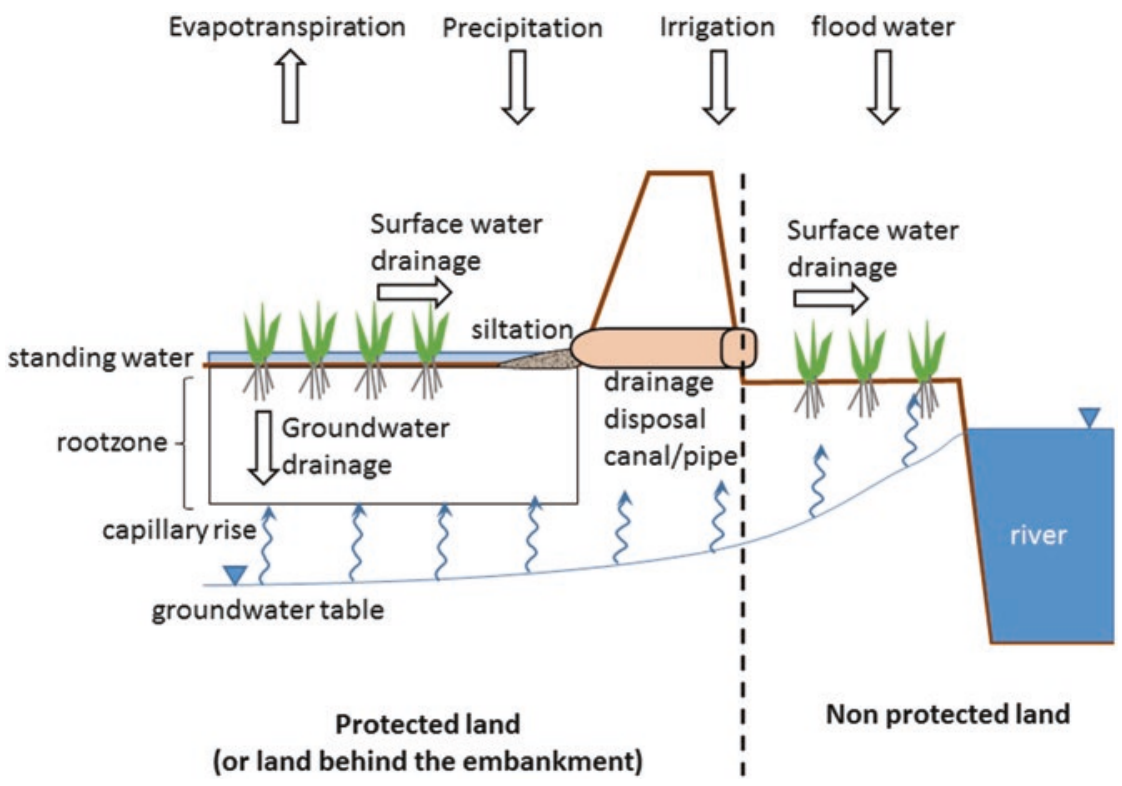

Fig. 28.5 Conceptual model of soil water and salt balance in $\triangle$ DIEM

irrigation are automatically calculated in $\triangle \mathrm{DIEM}$ following the methodology of the FAO CROPWAT model single layer approach (Clarke et al. 1998) and the salt balance model of Clarke et al. (2015). Daily soil salinity for a defined cropping pattern (a sequence of crop types grown on the same field) is calculated as an area averaged value of the soil salinity values beneath the grown crops. These crop-soil salinity time series are calculated both for the protected (i.e. poldered) and non-protected land of the Union with the results area averaged to produce a unique daily, Unionspecific soil salinity time series. Thus, the farm productivity calculations are tightly coupled with the water and salt balance calculations and also estimate the agro-economics (i.e. costs and returns to farmers).

\subsubsection{Process-Based Household Well-Being Calculations}

The process-based household well-being calculations are calculated for each Union at monthly time steps. Within each Union, 37 household archetypes are followed (Lázár et al. 2016). This module combines mod- 
elled bio-physical outputs (crop yields, required labour, fish catches), input scenarios (population, land cover/land use, economy) and observations from the household survey (see Chap. 23) to approximate household economics, poverty and health of the 37 household archetypes (Fig. 28.6). The household types are developed based on observed seasonal variations of the six occupation types: (i) farming (agriculture/ aquaculture/farm animals), (ii) farm labour, (iii) fishing, (iv) forest good collection, (v) manufacturing and (vi) business activities. Farming, farm labour and fishing are dynamically calculated in $\triangle D I E M$, whereas the others are input scenarios. Forest good collection is a static input as the basic ecosystem services of the mangrove forest (timber, fruits, honey, flood protection, etc.) are available in all mangrove species assemblages (see Chap. 26) and, as long as the forest is alive and is present, these services are available for the coastal populations. Finally, as non-ecosystem services-related livelihoods (businesses, services and manufacturing) are outside the scope of research, these use predefined economic scenarios that can be replaced by dynamic components when more detailed understanding and data become available.

At the heart of the household well-being calculations lies an optimisation routine that compares the income and fixed livelihood costs for each household type and approximates the affordable level for food, essential and nonessential house items, education, health and other expenses. This optimisation includes five coping mechanisms that can be activated under stressed economic conditions: (i) use cash savings, (ii) sell assets, (iii) get a formal loan, (iv) get an informal loan and (v) drop expenditure. The drop expenditure' option assumes the following order of expenditure reduction:

1. Reduce sporadic house expenses (house improvement), health-related expenses and other expenses (wedding, funeral, etc.)

2. Reduce non-essential house expenses (clothing, furniture, etc.)

3. Reduce education-related expenses

4. Reduce/drop direct livelihood costs

5. Delay loan repayment (if allowed) and reduce essential house expenses (cooking, heating, etc.)

6. Reduce food expenditure and under extreme conditions, rely on friends and family for support (if allowed by the user) 
A. N. Lázár et al.

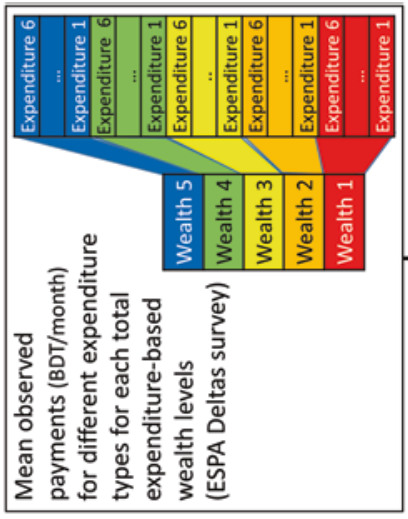

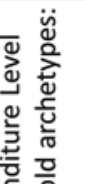

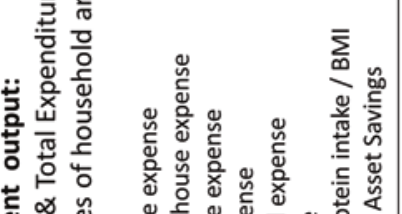

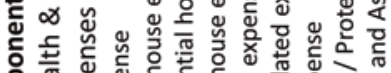

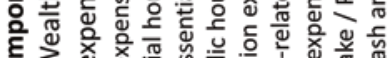
हั

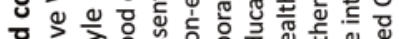

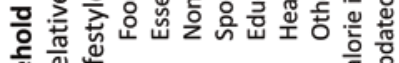

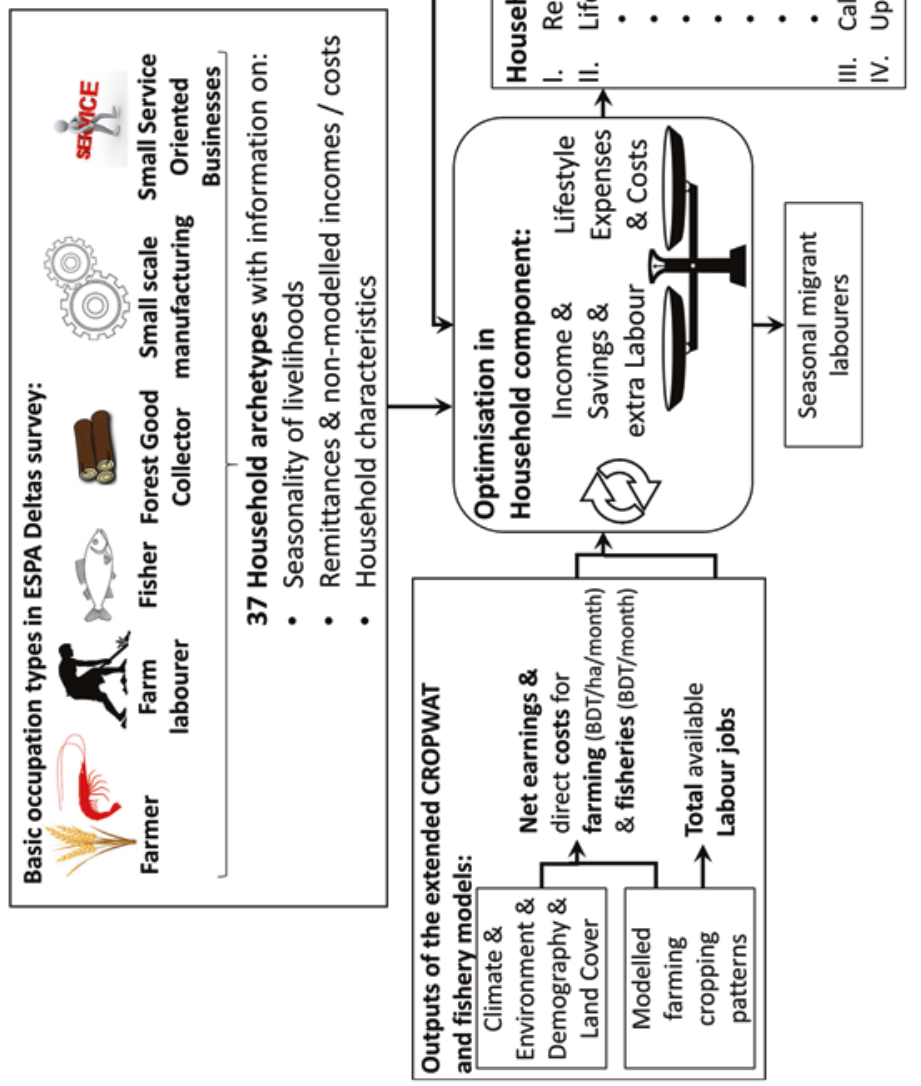

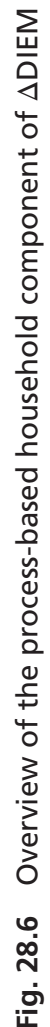


For household types that engage in farm labour, $\triangle$ DIEM also dynamically estimates the number of household members that engage in paid labour jobs, an additional coping strategy in stressed economic situations. The elderly and children are assumed not to be eligible for labour work, unless the household is in the lowest poverty categories (Wealth levels 1 and 2 on Fig. 28.6) and cannot afford the education expenses. The optimisation routine aims to ensure that the household saves a user-defined minimum fraction of the total monthly income (e.g. ten per cent) with the minimum number of household members engaging in labour works.

The outputs of this calculation are household expenditure levels and number of household members engaging in farm labour jobs. Food expenditure levels are assumed to represent different food baskets and thus food quality. Therefore, to estimate health, food expenditure was directly matched with observed levels of calorie- and protein-intake and body mass index (BMI) values based on the household survey dataset (see Chaps. 23 and 27). Finally, by knowing the monthly economics and calorie intake levels of the households, hunger periods of the household and other monetary poverty indicators of the region/community, such as GINI coefficient (i.e. income inequality) and gross domestic product (GDP)/capita, can be easily calculated.

\subsubsection{Statistical Associative Well-Being Calculation}

The statistical associative well-being calculation is completely independent from the process-based well-being calculations and operates at Union scale and annual time steps. Statistical associations were developed among observed land cover, land use, environmental quality, socio-economy and census-based asset poverty (see Chap. 21 and Amoako Johnson et al. 2016). This association is projected into the future within $\triangle$ DIEM, using dynamically modelled bio-physical calculations (soil salinity, waterlogging) and user-defined scenarios (land use, land cover, employment rate, literacy rate, children in school, travel time to cities). $\triangle$ DIEM estimates the likelihood of each Union being in the poorest asset poverty class for each year of the simulation. 


\subsubsection{The Software}

$\triangle \mathrm{DIEM}$ is developed in the MATLAB software development environment (MathWorks 2015). MATLAB is a high-level programming language capable of supporting multi-paradigm computations. MATLAB offers not only efficient calculation functions and routines but also allows, among others, plotting, mapping, graphical user interface (GUI) and parallel computing functionalities, thus providing a one-stop-shop model- and application-building environment. The r2015b version of MATLAB and the GUI Layout Toolbox version 2.2 are used to power the $\triangle$ DIEM calculations.

$\triangle \mathrm{DIEM}$ uses a large number of inputs and produces a numerous outputs (Tables 28.1 and 28.2). To support the user in effectively handling these, a GUI was developed that allows the user to change the inputs, run the model and plot the results by using predefined plotting routines.

Table 28.1 Key bio-physical and socio-economic inputs to the integrated model $\triangle$ DIEM

\begin{tabular}{lc}
\hline Bio-physical inputs & Socio-economic inputs \\
\hline I. Climate (daily) & VI. Demographic indicators (five-yearly) \\
$\begin{array}{l}\text { Precipitation, temperature, } \\
\text { evaporation, atmospheric CO } 2\end{array}$ & $\begin{array}{c}\text { Life expectancy, Total fertility rate, net } \\
\text { migration rate }\end{array}$ \\
concentration & VII. Economy (annual) \\
II. Upstream hydrology (daily) & Market price of crops/goods, cost of \\
River flow of the Ganges, & farm inputs, wages, future changes \\
Brahmaputra and Meghna river & of incomes/prices by 2030 when \\
system & compared to the present. Beyond \\
III. Bay of Bengal (daily) & 2030, all economic time series are \\
Mean sea elevation, subsidence, & kept constant to avoid unrealistic \\
cyclones/storm surges & market conditions \\
IV. Levees/polders & VIII. Governance \\
Location, height, (horizontal) & Future water share treaties, fishing \\
drainage rate & intensity, subsidies, loan types/ \\
V. Ecosystem services & characteristics, land cover/use, \\
Farming patterns (agriculture and & infrastructure planning and so on \\
aquaculture-pre-2000, present, & \\
near future, post-2050), & \\
irrigation water use, crop & \\
properties, offshore fish biomass & \\
(annual), land cover (1991, 2001, & \\
2011, 2050, 2100) & \\
\hline
\end{tabular}


Table 28.2 Key bio-physical and socio-economic outputs from the integrated model $\triangle$ DIEM

\begin{tabular}{|c|c|}
\hline Bio-physical outputs (daily results) & $\begin{array}{l}\text { Socio-economic outputs (monthly } \\
\text { results) }\end{array}$ \\
\hline $\begin{array}{l}\text { I. Environment } \\
\text { Water elevation, inundated area/ } \\
\text { depth, waterlogging, soil moisture, } \\
\text { river/groundwater/soil salinity } \\
\text { II. Unit area-based productivity } \\
\text { Crop productivity (agriculture and } \\
\text { aquaculture), fish catches, economic } \\
\text { cost-benefits of farming and fishing } \\
\text { (income/costs/net earnings) }\end{array}$ & $\begin{array}{l}\text { I. Household outputs } \\
\text { (a) Bayesian statistical module: } \\
\text { asset-based relative poverty } \\
\text { indicator } \\
\text { (b) Process-based module: } \\
\text { economics (income, costs/ } \\
\text { expenses, savings/assets), } \\
\text { relative wealth-level, calories/ } \\
\text { protein intake/BMI, monetary } \\
\text { poverty } \\
\text { II. Regional economic indicators } \\
\text { Sectoral output (tons, BDT), GINI, } \\
\text { GDP/capita, potential income } \\
\text { tax revenue, household debt } \\
\text { level }\end{array}$ \\
\hline
\end{tabular}

Due to the detailed daily soil salinity and farming calculations and the large number of simulated Unions $(N=653), \triangle \mathrm{DIEM}$ is still computationally intensive. Even though the Union-specific calculations are done with parallel computing, a 50-year run of the 653 Unions for one scenario requires -7 hours computation time on a four-core computer (2.70GHz processor, 16GB RAM, 64-bit Win7 operation system). To make the calculations more effective, $\triangle$ DIEM is being run on IRIDIS4, the supercomputer of the University of Southampton. In this way, each scenario takes only four hours to run, and all the scenarios can be initiated at the same time. The user has the option to save all results (17GB per scenario) or just the most important model results (5.8 GB per scenario). Currently, $\triangle \mathrm{DIEM}$ has a version number of 1.02 .

\subsubsection{Testing and Validating the Model}

Model testing/validation and sensitivity/uncertainty analysis are essential parts of model development. Full model validation is not possible for complex, natural system models (Oreskes et al. 1994) and this is especially 
true for $\triangle$ DIEM. Model testing was carried out at three levels: (i) Code verification checks the code for bugs to ensure that the model behaves as designed. (ii) Component testing checks each individual model element in isolation from the rest of the integrative model to test that the behaviour matches the observations and/or the simulator behaviour (e.g. the goodness of fit of the emulator compared to the Delft-3D model outputs is being tested). Component testing also includes sensitivity tests that aim to explore the behaviour of individual components. Ultimately, when the code is 'bug free' and the individual components worked satisfactorily, the (iii) global model results are assessed and validated for their emergent behaviour. The component testing and global analysis results are presented in Appendix 1 of this chapter.

\subsection{Overview of the Scenarios Used in $\triangle$ DIEM}

The model uses harmonised, consistent scenarios and combines three climate scenarios with three development scenarios creating nine distinct and plausible futures for coastal Bangladesh (see Chap. 9). The key assumptions of the $\triangle \mathrm{DIEM}$ scenarios are described here; see Appendix 2 for the quantified model inputs by scenarios used in $\triangle$ DIEM.

\subsubsection{Climate}

The climate scenarios used the downscaled Bangladesh projections discussed in Chap. 11. When calculating summary statistics for the study area, results are different to regional projections (i.e. South Asia, including the GBM catchments) as shown in Table 28.3. The table shows that projected temperature changes in the study area are anticipated to be slightly lower than the regional projections but they show the same relative pattern with the highest temperature rise under the Q16 scenario. On the other hand, precipitation over the twenty-first century increases until 2050 in all scenarios and slightly decreasing thereafter under Q0. 
Table 28.3 Comparison of regional and study area forecasts of the HadRM3/ PRECIS Regional Climate Model scenarios (SRES A1B, RCP 6.0-8.5). Significant differences are shown in bold

\begin{tabular}{|c|c|c|c|c|}
\hline \multirow{2}{*}{$\begin{array}{l}\text { Scenario } \\
\text { name }\end{array}$} & \multicolumn{2}{|c|}{$\begin{array}{l}\text { Annual change by } 2041-2060 \\
\text { relative to } 1981-2000\end{array}$} & \multicolumn{2}{|c|}{$\begin{array}{l}\text { Annual change by } 2080-2099 \\
\text { relative to } 1981-2000\end{array}$} \\
\hline & Regional & Study area & Regional & Study area \\
\hline \multicolumn{5}{|c|}{ Temperature change } \\
\hline $\mathbf{Q}_{0}$ & $+2.20^{\circ} \mathrm{C}$ & $+2.17^{\circ} \mathrm{C}$ & $+3.90^{\circ} \mathrm{C}$ & $+3.78^{\circ} \mathrm{C}$ \\
\hline $\mathrm{Q}_{8}$ & $+2.45^{\circ} \mathrm{C}$ & $+2.34{ }^{\circ} \mathrm{C}$ & $+3.98{ }^{\circ} \mathrm{C}$ & $+3.87^{\circ} \mathrm{C}$ \\
\hline $\mathbf{Q}_{16}$ & $+2.65^{\circ} \mathrm{C}$ & $+2.53^{\circ} \mathrm{C}$ & $+4.75^{\circ} \mathrm{C}$ & $+4.39^{\circ} \mathrm{C}$ \\
\hline \multicolumn{5}{|c|}{ Precipitation change } \\
\hline $\mathbf{Q}_{0}$ & $+8.26 \%$ & $+10.42 \%$ & $+11.75 \%$ & $+9.93 \%$ \\
\hline $\mathrm{Q}_{8}$ & $-1.35 \%$ & $+8.70 \%$ & $+13.01 \%$ & $+10.28 \%$ \\
\hline $\mathbf{Q}_{16}$ & $+10.28 \%$ & $+10.22 \%$ & $+23.66 \%$ & $+11.36 \%$ \\
\hline
\end{tabular}

However, these multi-decadal change-indicator values, especially for precipitation, are not useful for analysis. Figure 28.7 shows the mean annual and five-year smoothed precipitation and temperature values. It is clear that the inter-annual variation in precipitation is significant and a clear trend is not obvious. On the other hand, temperature, with slight interannual variations, is steadily increasing under all scenarios. Note that the climate scenarios are different for the historical period.

The climate scenarios are important for $\Delta$ DIEM's hydrological, coastal flooding, fishery and agriculture productivity calculations. Figure 28.8 explores some of the drivers of change in the study area under three illustrative scenarios: (i) Q16 Less Sustainable (LS), (ii) Q8 Business As Usual (BAU) and (iii) Q0 More Sustainable (MS). The plots show five-year moving averages to make trends visible. As Fig. 28.7 already indicated, the Q16LS scenario is the driest of the three climate scenarios. The mean annual river flow to the study area is much lower than for the other climate scenarios. Similarly, the number of days with potential floods $\left(\geq 77,000 \mathrm{~m}^{3} / \mathrm{s}\right)$ is the lowest, and the number of baseflow days $\left(\leq 5,500 \mathrm{~m}^{3} / \mathrm{s}\right)$ is the highest in Q16LS. This allows more saltwater intrusion along river channels (i.e. high river salinity during the dry season). At the same time, the total dry season precipitation is the lowest for the Q16 scenario with the highest number of dry days and dry consecutive 

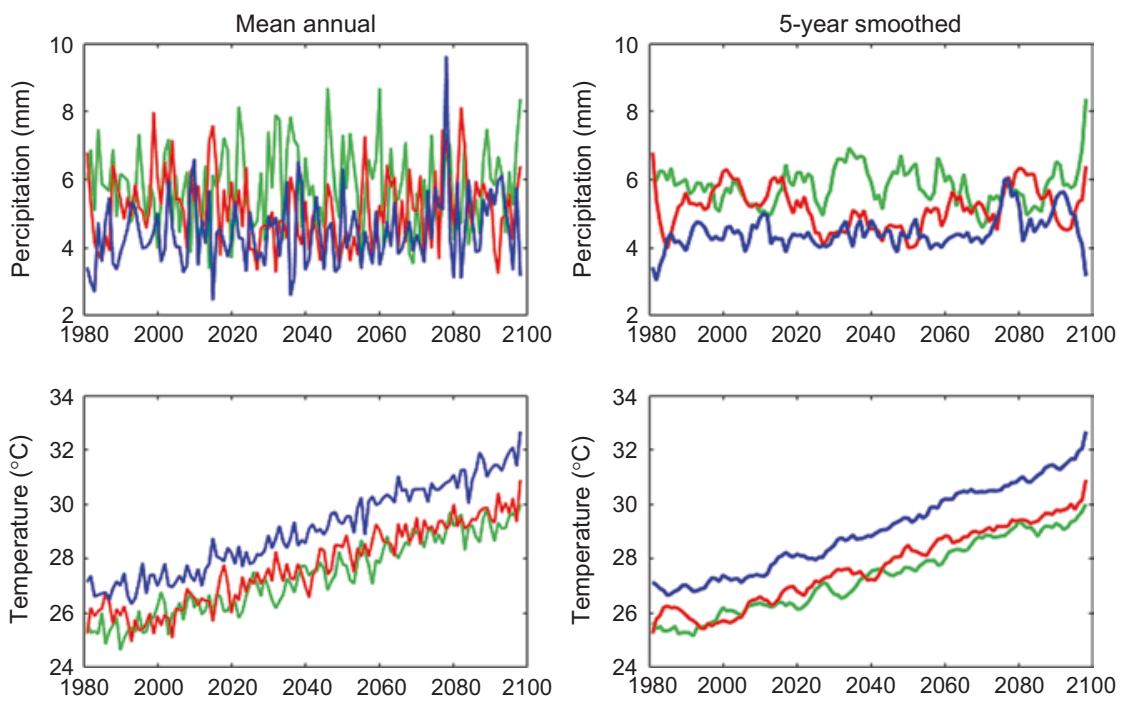

$$
-\mathrm{Q} 0-\mathrm{Q} 8-\mathrm{Q} 16
$$

Fig. 28.7 Mean annual precipitation and temperature scenarios for the study area

days. This is the worst case scenario for dry season agriculture where good quality irrigation water is only available from groundwater sources and, without irrigation, no crops can be grown. For the other climate scenarios $(\mathrm{Q} 0, \mathrm{Q} 8)$, the river flow seems to slightly increase over time, together with more flood flows and less baseflow. Dry season precipitation has significant inter-annual variability, and thus, the availability depends on which year/period is considered. The 'maximum consecutive dry days' plots have similar values to Q16 ( -30 days), indicating that the precipitation will be more intense and comes with a similar frequency.

In summary, the climate scenarios show that the Q0 scenario will increase the variability of available total precipitation with somewhat higher river flows and more intense dry season precipitation (Fig. 28.5). The Q8 scenario shows a decreasing precipitation availability in the coastal zone; however, the upstream river discharges will not be smaller. 

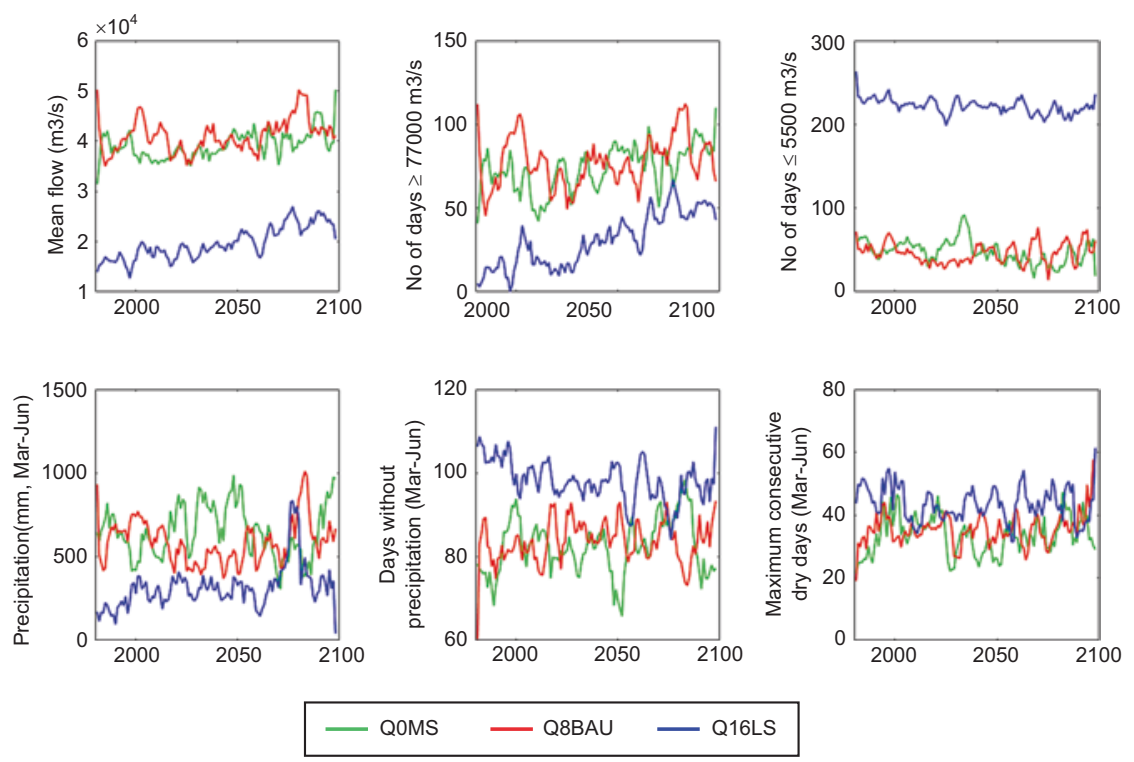

Fig. 28.8 Five-year smoothed river flow statistics (top row) and dry season precipitation trends (bottom row) for coastal Bangladesh under three future scenarios

Q16 is the driest scenario of the three sets but, when analysed by itself, Q16 shows a gently increasing total precipitation trend by 2050 beyond which the total dry season precipitation can greatly increase.

\subsubsection{Fisheries}

Potential fish catches under climate change and management scenarios in $\triangle \mathrm{DIEM}$ are directly used from the output projections of SS-DBEM model (see Chap. 25 and Fernandes et al. 2016). The fisheries model projects a decrease of fish availability and catches under all scenarios with a plausible collapse of fisheries (specifically the Hilsha fishery) under the high overfishing scenario if the management does not change. However, if current catches are compared under business-as-usual and sustainable fishing, current catches could be maintained (Fernandes et al. 2016). In $\triangle D I E M$, the fisheries model results are reduced by export 
quantities (i.e. outside the study area) and then distributed to each of the nine districts of the study area based on observations (i.e. statistical yearbook data). Within each district, the caught fish are then distributed to each household archetype based on their fishing intensity and the number of fishers.

\subsubsection{Agriculture}

The agriculture component of $\triangle \mathrm{DIEM}$ is built on a review of observed past (1990s) and present (2010) cropping patterns (i.e. sequence of crops on agriculture fields) aiming to identify typical crops, their varieties and their use in coastal Bangladesh. The five most frequent cropping patterns for each Upazila (i.e. sub-district) is based on the soil survey reports of Bangladesh. The copping patterns are assumed to be the same in each Union within a specific Upazila, and the per cent area used for each cropping pattern is the same as the observed. Table 28.4 shows the agriculture cropping pattern assumptions used in $\triangle \mathrm{DIEM}$. The properties of the observed crops (rooting depth, crop coefficient, evaporation depletion factor, salinity tolerance, etc.) are partially collated from field observations (datasets from Bangladesh Agricultural Research Institute [BARI], Bangladesh Rice Research Institute

Table 28.4 Development scenarios for agriculture used in the integrated model

\begin{tabular}{|c|c|c|c|}
\hline \multirow[b]{2}{*}{ Scenario } & \multicolumn{3}{|l|}{ Time period } \\
\hline & (i) Present & (ii) 2041-2060 & (iii) 2080-2099 \\
\hline \multirow[t]{2}{*}{$\begin{array}{l}\text { Less } \\
\text { Sustainable }\end{array}$} & $\begin{array}{c}\text { Current crop } \\
\text { properties }\end{array}$ & $\begin{array}{c}\text { Current crop } \\
\text { properties }\end{array}$ & Current crop properties \\
\hline & $\begin{array}{l}2010 \text { cropping } \\
\text { patterns }\end{array}$ & $\begin{array}{l}1990 \text { cropping } \\
\text { patterns }\end{array}$ & 1990 cropping patterns \\
\hline \multirow[t]{2}{*}{$\begin{array}{l}\text { Business As } \\
\text { Usual }\end{array}$} & $\begin{array}{c}\text { Current crop } \\
\text { properties }\end{array}$ & $\begin{array}{c}\text { Current crop } \\
\text { properties }\end{array}$ & $\begin{array}{l}\text { Increased yield and } \\
\text { salt-tolerant varieties }\end{array}$ \\
\hline & $\begin{array}{l}2010 \text { cropping } \\
\text { patterns }\end{array}$ & $\begin{array}{l}2010 \text { cropping } \\
\text { patterns }\end{array}$ & 2010 cropping patterns \\
\hline \multirow[t]{2}{*}{$\begin{array}{l}\text { More } \\
\text { Sustainable }\end{array}$} & $\begin{array}{l}\text { Current crop } \\
\text { properties }\end{array}$ & $\begin{array}{l}\text { Increased yield and } \\
\text { salt-tolerant } \\
\text { varieties }\end{array}$ & $\begin{array}{l}\text { More increased yield } \\
\text { and tolerant varieties } \\
\text { (salt, flood tolerant) }\end{array}$ \\
\hline & $\begin{array}{l}2010 \text { cropping } \\
\text { patterns }\end{array}$ & $\begin{array}{l}2010 \text { cropping } \\
\text { patterns }\end{array}$ & 2010 cropping patterns \\
\hline
\end{tabular}


[BRRI] and Department of Agricultural Extension [DAE]) and partially based on a model calibration exercise described in Lázár et al. (2015). To anticipate future crop varieties, properties of future crops (potential yield and salinity tolerance) are modified based on information published in 'Agricultural Technology for Southern Region of Bangladesh' report (BARC 2013). Other basic crop properties that affect water uptake and other tolerances (e.g. temperature) are not changed compared to the existing crops. Over time, cropping patterns change by considering a five-year overlap (i.e. transition period) between the 'old' and 'new' cropping patterns.

\subsubsection{Land Use}

Historical land cover and land use were identified from remote sensing images for 1989, 2001 and 2011 (see Chap. 21 and Amoako Johnson et al. 2016). Future land cover scenarios, on the other hand, were developed based on a national stakeholder workshop in Bangladesh, where the LS, BAU and MS scenarios were qualitatively described (see Chaps. 10 and 20). These narratives were quantified and then validated during a national technical expert workshop again in Bangladesh (Table 28.5).

\subsubsection{Demography}

The demographic scenarios are based on the analysis discussed in Chap. 19 (see also Szabo et al. 2015). This work anticipates that the coastal population will decrease from around 14 million in 2011 to about 11-13.5 million in 2050, depending on the development scenario in question. The LS scenario assumes the highest level of out migration, whereas MS assumes the least migration.

\subsubsection{Economic Trends}

Historical economic time series were collated from different statistical yearbooks and Household Income and Expenditure Survey datasets for coastal Bangladesh. The present-day economic data were collected 
Table 28.5 Land cover and land use development scenarios for the study area

\begin{tabular}{lllll}
\hline $\begin{array}{l}\text { Per cent reduction by 2050/by 2100 } \\
\text { (compared to present-day land } \\
\text { cover) }\end{array}$ & $\begin{array}{l}\text { Gain of } \\
\text { agriculture }\end{array}$ & $\begin{array}{l}\text { Gain of } \\
\text { aquaculture }\end{array}$ & $\begin{array}{l}\text { Gain of } \\
\text { bare land }\end{array}$ \\
\hline $\begin{array}{l}\text { Less Sustainable } \\
\text { Loss of Sundarbans } \\
\text { (encroaching) }\end{array}$ & $20 / 25 \%$ & $0 / 0 \%$ & $20 / 25 \%$ & \\
$\begin{array}{l}\text { Loss of other mangroves } \\
\text { Reduce agriculture if } \\
\text { salinity: high }\end{array}$ & $10 / 10 \%$ & $5 / 5 \%$ & $5 / 5 \%$ & $20 / 20 \%$ \\
$\begin{array}{l}\text { Reduce agriculture if } \\
\text { salinity: moderate }\end{array}$ & $10 / 10 \%$ & & & $10 / 10 \%$ \\
$\begin{array}{l}\text { Reduce agriculture if } \\
\text { salinity: low }\end{array}$ & $0 / 0 \%$ & & & \\
$\begin{array}{l}\text { Business As Usual } \\
\text { Loss of Sundarbans } \\
\text { (encroaching) }\end{array}$ & $10 / 15 \%$ & $5 / 7.5 \%$ & $5 / 7.5 \%$ & \\
$\begin{array}{l}\text { Loss of other mangroves } \\
\text { More Sustainable } \\
\text { Loss of Sundarbans } \\
\text { (encroaching) }\end{array}$ & $5 / 10 \%$ & $2.5 / 2.5 \%$ & $2.5 / 2.5 \%$ & \\
$\begin{array}{l}\text { Loss of agriculture } \\
\text { Loss of agriculture } \\
\text { (coastal Unions) }\end{array}$ & $5 / 2 \%$ & $2.5 / 1 \%$ & $2.5 / 1 \%$ & \\
\hline+ Land zoning scenarios based on FAO and MA (2013) assuming a 30 per cent \\
increase in the promoted sector
\end{tabular}

through the household survey. Future economic scenarios were developed based on a microeconomic study (see Chap. 12). This analysis estimates expected changes by 2030 (from present-day) for a number of broad economic variables (Table 28.6). At present, no further change is assumed beyond 2030 due to high level of uncertainties in economic trends and to avoid unrealistic 'market' situations. Prices, wages and costs are generally going to increase, with a higher level of increase under the MS future, although there are some exceptions (e.g. aquaculture, services and manufacturing). Incomes are expected to increase for farming and fishing. However, the value of forest goods is expected to decrease in each economic scenario. Note the very high increase in income from services and manufacturing (bold) compared to any other economic increase. The socio-variables (employment rate, literacy rate, children in school, travel time to cities) are all expected to improve by 2030 . 
Table 28.6 Percentage change in $\triangle$ DIEM economic input variables by 2030 . Figures in bold highlight the increase in income from services and manufacturing

\begin{tabular}{|c|c|c|c|}
\hline Economic input variable & $\begin{array}{l}\text { Less } \\
\text { Sustainable }\end{array}$ & $\begin{array}{l}\text { Business As } \\
\text { Usual }\end{array}$ & $\begin{array}{l}\text { More } \\
\text { Sustainable }\end{array}$ \\
\hline $\begin{array}{l}\text { Cost of agriculture (seed, pesticide, } \\
\text { fertiliser types) }\end{array}$ & 0 & 10 & 20 \\
\hline $\begin{array}{l}\text { Cost of aquaculture (feed, post } \\
\text { larvae, fishling) }\end{array}$ & 20 & 10 & 0 \\
\hline $\begin{array}{l}\text { Cost to keep livestock/poultry, } \\
\text { fishing, forest collection }\end{array}$ & 0 & 10 & 20 \\
\hline Land rent cost (farming) & 0 & 10 & 20 \\
\hline $\begin{array}{l}\text { Cost to undertake services and } \\
\text { manufacturing business }\end{array}$ & 20 & 0 & -20 \\
\hline $\begin{array}{l}\text { Market (selling) price of agriculture } \\
\text { crops }\end{array}$ & 0 & 10 & 20 \\
\hline Market (selling) price of fish & 30 & 10 & 20 \\
\hline $\begin{array}{l}\text { Market (selling) price of } \\
\text { aquaculture crops (shrimp) }\end{array}$ & 0 & 10 & 20 \\
\hline $\begin{array}{l}\text { Income from forest goods (honey, } \\
\text { fruits, timber, etc.) }\end{array}$ & -20 & -10 & 0 \\
\hline $\begin{array}{l}\text { Income from manufacturing, } \\
\text { services and livestock/poultry }\end{array}$ & 65 & 110 & 165 \\
\hline Remittances (BDT/month) & 20 & 30 & 40 \\
\hline Household expenses & 0 & 10 & 20 \\
\hline $\begin{array}{l}\text { Daily wage (without food) (BDT/ } \\
\text { day) }\end{array}$ & 0 & 10 & 30 \\
\hline Cost of diesel (BDT/gallon) & 0 & 10 & 20 \\
\hline Employment rate (\% population) & 0 & 10 & 30 \\
\hline Literacy rate (\% population) & 2 & 4 & 8 \\
\hline Children in school (\% population) & 2 & 5 & 10 \\
\hline Travel time to major cities & -10 & -30 & -50 \\
\hline $\begin{array}{l}\text { USD/BDT exchange rate and PPP } \\
\text { exchange rate }\end{array}$ & 0 & 0 & 0 \\
\hline
\end{tabular}

\subsection{Illustrative $\Delta$ DIEM Outputs}

The review of boundary conditions indicates the Q16LS scenario combination is possibly the worst future, due to the importance of agriculture in the study area, while the Q0MS combination represents the best plausible future. To illustrate this, and to limit the number of plots presented, only results for a diagonal transect of the modelled nine plausible futures are presented here, namely, the Q16LS, Q8BAU and Q0MS scenarios. 


\subsubsection{Composite Indicators Used in $\triangle$ DIEM}

In order to compare the different scenarios effectively, composite indicators are used to describe the environmental hazards, the provisioning ecosystem services and the resulting socio-economic situation. The elements of these composite indicators are:

\section{Environmental hazards}

(a) Drought index

- Number of days when total river inflow is the below the 20 percentile flow

- Number of days with no precipitation in the dry season (March-June)

- Maximum number of consecutive dry days in the dry season (March-June)

(b) Flood index

- Number of days when the total river inflow exceeds the 90 percentile flow

- Number of days when the soil is inundated with a minimum of $25 \mathrm{~cm}$ deep water. This considers fluvial and coastal floods and water accumulation on the soil surface due to intense precipitation.

(c) Soil salinity index (area averaged, March-June)

\section{Provisioning ecosystem services}

(a) Farm income (population averaged)

(b) Fishing income (population averaged)

(c) Off-farm, non-ecosystem service related income (population averaged) 


\section{Socio-economic situation}

(a) Food security

- Calorie intake (population averaged)

- Protein intake (population averaged)

- Body mass index (BMI, population averaged)

(b) Income inequality index (GINI coefficient)

All indicators are normalised to the minimum/maximum range for plotting purposes. Figure 28.9 presents the results for the selected three scenarios. The inter-annual variability is the greatest for the environmental hazard, moderate for the provisioning ecosystem services and minimal for the socio-economic indicators. This immediately indicates that the socio-economic conditions have greater influence on the results than the changes in the quality of the environment.
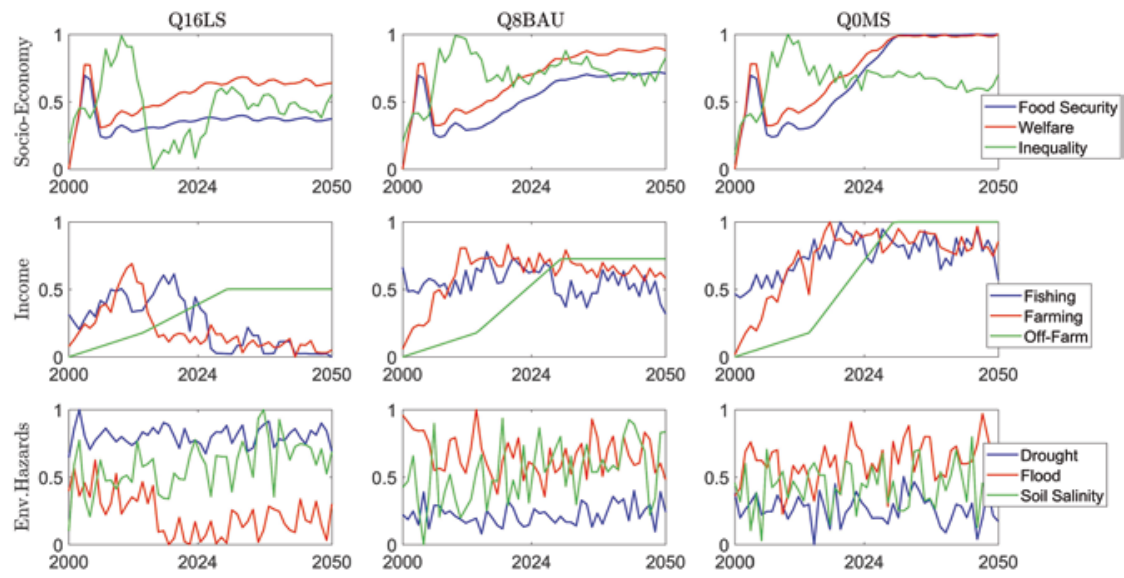

Fig. 28.9 Normalised composite indicator outputs of the $\triangle$ DIEM simulations under three future scenarios. Note $y$-axis values: ' 0 ' means low level, ' 1 ' means high level 


\subsubsection{Results for Selected Indicators}

The Q16LS scenario indicates a moderate reduction in the prevalence of poverty and food security, but a collapse of rural income (i.e. farming and fishing) and an enhanced off-farm sectors (this is a scenario and is not dynamically modelled). Income inequality (i.e. GINI), after a sudden drop associated with a significant decrease of farming incomes, gently rises after 2025 with some inter-annual variation. Even though soil salinisation intensifies, drought and the return to the traditional 1990 farming practices drive the collapse of farming. Flooding is minimal under this scenario due to low river flows.

The Q8BAU scenario shows a moderate increase in welfare and food security. Inequality is the highest indicating the largest difference between the most poor and the least poor households. Fishing income has a gradual downward trend implying an unsustainable use of fisheries. Farming livelihood similarly declines due to increasing salinisation. Drought also becomes more frequent after 2040. Even though flooding intensity has a high inter-annual variability, it does not have a long-term trend.

The Q0MS scenario has an enhanced agriculture (present-day practices but more resilient crops), sustainable fisheries and intensified off-farm activities. This diversity results in large improvements in poverty and food security. However, income inequality is not lower when compared to the other scenarios. This implies that, while the poorest benefit from favourable economic and environmental conditions, the income gap remains. Due to the economic stability of region, inequality starts to decrease very slightly after 2025. The composite hazard indicators indicate an increase in flood intensity and slight decrease in drought. Soil salinity is highly variable, but this scenario has the lowest soil salinity levels.

Soil salinity in $\triangle \mathrm{DIEM}$ is the result of climatic (precipitation, temperature), environmental (drainage, capillary rise, flooding) and anthropogenic (irrigation) factors. Considering the three highlighted scenarios, simulations show a slight increase in soil salinity from 2010 to 2050 under all futures. The categories in Fig. 28.9 correspond to critical soil salinity thresholds. For example, above four deciSiemens per metre $(\mathrm{dS} / \mathrm{m})$, vegetables generally do not grow, and above $8 \mathrm{dS} / \mathrm{m}$, most rice varieties stop growing. This makes farming livelihoods very challenging during the dry 


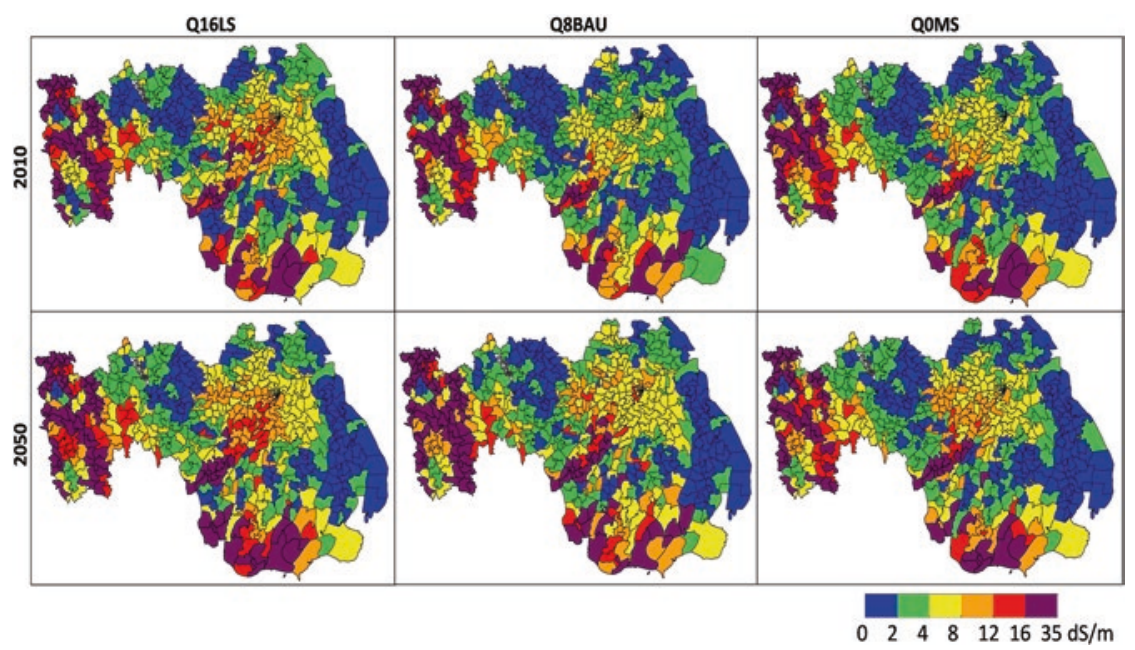

Fig. 28.10 $\triangle$ DIEM soil salinity results for 2010 and 2050 (Union average)

season and might force the farmers into off-farm livelihoods during the driest months. Figure 28.10 indicates that the already high soil salinity levels found in the coastal fringe and Khulna and Satkhira districts (the western part of the study area) in 2010 become slightly worse. In the central Barisal division (the north-east), soil salinity increases by one category in many Unions between 2010 and 2050. This means that this region, which traditionally has three agriculture crops per year, will require careful management to be able to produce rabi (dry season) crops. Finally, the less sustainable scenarios result in the largest soil salinisation (spatial extentwise). The main driver of soil salinisation in the model simulations is the salinity of the irrigation water.

Soil salinity is just one factor affecting farm productivity, but it is often thought to be the most important. Figure 28.11 shows the crop potential for the study area in general (i.e. over the year) and for the rabi (dry) season. When the 'all crop' maps are compared to the soil salinity maps, the crop potential results are somewhat similar. However, the dry season situation is strikingly different. This is because drought becomes more limiting than soil salinity in the simulations. This is especially true under the Q16 climate scenario, where drought is significantly worse than in 


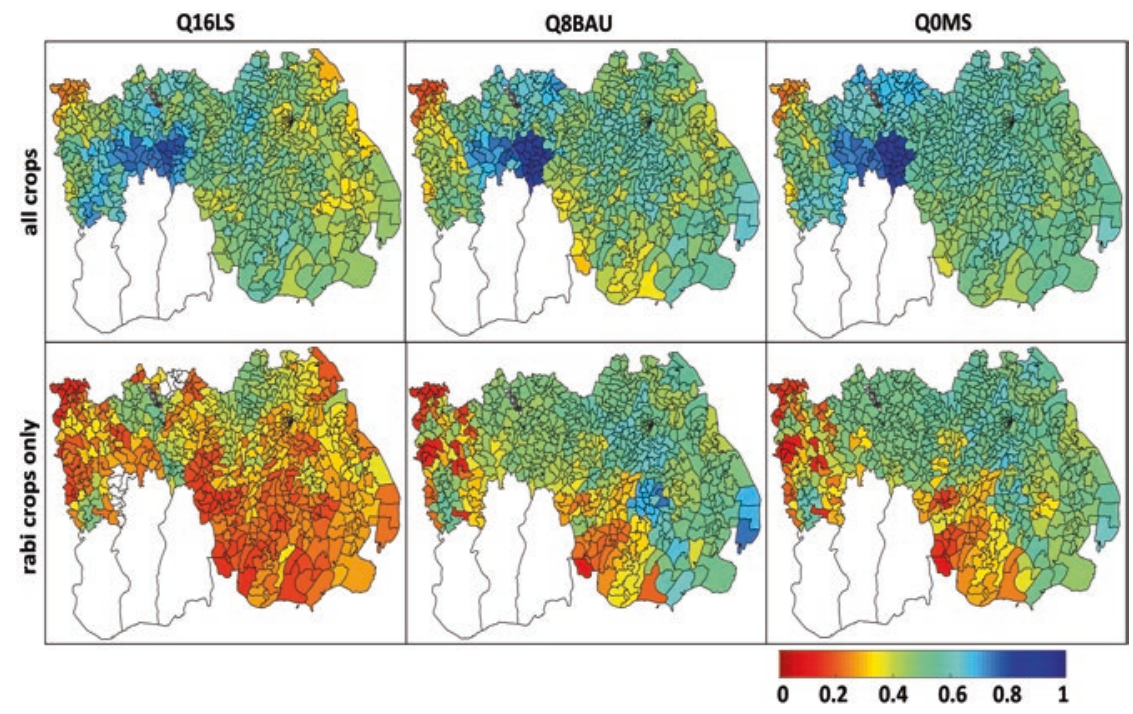

Fig. 28.11 Simulated crop potential in $\mathbf{2 0 5 0}$ for the overall year (top panels) and for the rabi (dry) season (lower panels) (Note: ' 1 ' indicates maximum potential, ' 0 ' indicates no potential)

the other climate scenarios. The western part of the study area remains close to the maximum crop potential (i.e. dark blue), even though the soil salinity values are high. This is a consequence of the cropping pattern scenarios that assume that shrimp farming is significant there.

Whether a household can make a decent living from farming depends on the crop yield, the market price of the crop, the direct costs associated with the crop production and the land size. For example, the farmers that have homestead-size farm (0.01-0.5 acre) earn on average 500 Bangladesh taka (BDT) per month. A small land owner (0.5-2.5 acre) earns about 2,000 BDT per month and a large land owner ( $>2.5$ acre) 15,000 BDT per month, when selling crops on the open market. This is however not the actual net earnings of the household from farming as direct agriculture costs can consume almost the entire farm income. Net earnings (i.e. income minus costs), and thus the household income, increases with the land area and cultivation efficiency. Thus, the larger the land area, the more profit remains for the farming household. 

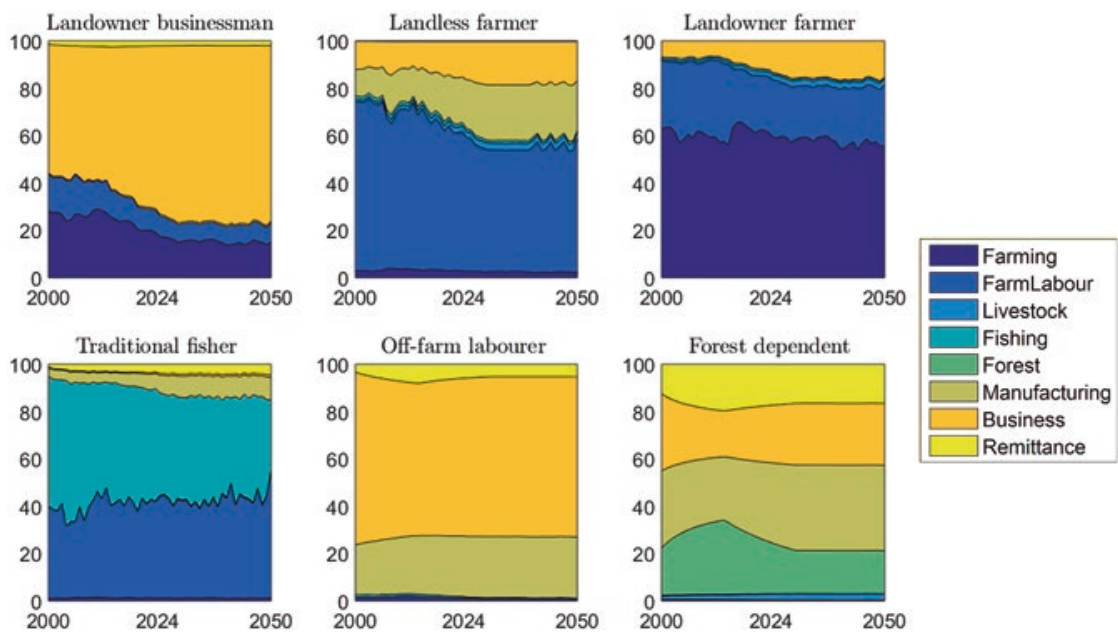

Fig. 28.12 Trajectory of simulated livelihood income composition (as percentage of total income) for six selected household archetypes under the Q8BAU scenario

$\triangle \mathrm{DIEM}$ also allows the dominance of income type for the defined household archetypes (Lázár et al. 2016) to be investigated over time. Figure 28.12 shows the importance of livelihoods for six selected household archetypes which illustrate the spread of livelihood strategies and associated land sizes within the study area. The total number of household archetypes found in the survey (37) means that the population percentage identified in each category is generally low: business-business-business (large land owner, two per cent of population), farming-farming-farming (landless, nine per cent of population), farming-farming-farming (large land owner, one per cent of population), fishing-fishing-fishing (landless, three per cent of population), business-manufacturing-business (landless, ten per cent of population) and forest dependent (less than one per cent of population). However, it is clear that ecosystem services-based livelihoods decline in importance over time for all household types. Wealthy land owner businessmen start with a fairly balanced income distribution, but by the end of the simulation, they predominantly rely on off-farm business activities (i.e. not ecosystem servicebased). The landless farmer archetype has marginal land, but pond-based 
aquaculture and farm labour provide the bulk of their income. The land owner farmer archetype has enough land to sustain their well-being, with occasional farm labour and some business activities providing an extra income. Fishing and livestock provide the livelihood for the traditional fisher archetype with increasingly limited fishing income. The off-farm labourer archetype only undertakes off-farm activities, whereas the forest-dependent archetype does both ecosystem service-based and off-farm activities with no significant change in income dominance.

\subsubsection{Summary of Findings}

The study area in Bangladesh gradually develops under all scenarios, but the level of improvement depends on the future population dynamics and the economic situation. Present-day agriculture-based livelihoods are constrained by land availability, dry season salinity and agro-economics. Monsoon rains supply adequate water to grow a main season rice crop but farmers' incomes are constrained by the market price for rice compared with the direct agriculture costs (i.e. allows no or only a modest profit). However, second and third crops grown in the drier months require irrigation even today. Low irrigation water quality contributes to soil salinisation reducing farm production potential. Future crop production, however, is also likely to be constrained by drought (i.e. lack of water and high air temperature). The development of drought and salt-tolerant varieties of rice and other crops is in progress and will be essential to sustain and improve production under the future scenarios considered here. Fisheries also require careful management to avoid a collapse of fish stocks. In addition to the provisioning ecosystem services (agriculture, fisheries), interannual variability is also significant for environmental hazards (i.e. floods).

To 2050, when strong cyclone and storm surge activities are not considered, household socio-economics appear largely decoupled from climate and environmental change although strongly related to future population dynamics. This means that non-ecosystem services-based income sources can maintain well-being even though the traditional fishing and farming-based livelihoods become less and less profitable and potentially unsustainable under the LS and BAU socio-economic 
scenarios. Therefore, governance related to market conditions, job opportunities and access to resources and markets has a critical impact on the future welfare of the study area. However, a word of caution needs to be raised: even though the economy and well-being of the population can increase under appropriate governance and social policies, environmental change can still have a detrimental effect on the food security for Bangladesh. For example, soil salinity, together with household socioeconomic characteristics, is one of the main explanatory variables of food security for coastal households (negative effect) regardless of wealth levels (Szabo et al. 2015). In the modelling discussed here, soil salinisation is likely to continue and even accelerate after 2050 due to sea-level rise and subsidence. Furthermore, increasing future cyclone frequency and magnitude together with increasing sea-level rise can be catastrophic for agriculture and, through damage, can impact all sectors in the coastal zone. Therefore, appropriate adaptation will be required to sustain an ecosystem service rich coastal zone and food-secure coastal population. This might include some combination of enhanced polders, tidal river management, water diversions and nature-based approaches. Such adaptation requires additional assessment.

\subsection{Conclusions}

This chapter presents the vision, design and summary results of a novel integrated assessment model, the Delta Dynamic Integrated Emulator Model $(\triangle \mathrm{DIEM}) . \triangle \mathrm{DIEM}$ is a holistic integrated assessment framework coupling bio-physical and socio-economic changes with governance to assess livelihoods, poverty and health of the rural coastal population in Bangladesh. The model strongly builds on the expertise and results of the research undertaken and utilises high fidelity models, statistical associations and observations including a bespoke household survey dataset. $\triangle$ DIEM was successfully tested and validated against both the high fidelity models and observations, and thus the results represent the observed system of coastal Bangladesh well.

$\triangle \mathrm{DIEM}$ is being used to integrate consistent bio-physical and socioeconomic scenarios developed across the project, initially up to 2050 . 
The presented results show the economy, and thus the generic well-being is expected to steadily increase across all scenarios, although the rate of change will depend on governance. Ecosystem services are, however, expected to decline by 2050 across all three scenarios. In the least desirable world, both agriculture and fisheries collapse, but even under the more sustainable scenario, both fish catches and farm productivity decline slightly due to environmental stress such as soil salinisation and heat stress on crops. Therefore, even though economic development can decouple from ecosystem service trends, the future food security of Bangladesh and the sustainability and habitability of the coastal zone will depend on how the extreme events and persistent environmental processes are managed, and what adaptation and development is implemented.

The integrated analysis capacity that $\triangle D I E M$ provides was previously non-existent in the literature. It is crucial to integrate the available knowledge to understand and analyse the big picture (environment, socio-economy, welfare together) to be well prepared for the challenges that climate and environmental change and a shift in macroeconomics might bring in the future. The $\triangle \mathrm{DIEM}$ approach is the first of its kind to combine top-down and bottom-up approaches while tightly coupling climate environmental, demographic, social behaviour, economics and governance at the relevant scale of decision making. Decision makers have to be aware of cause-effect relationships and long-term trends to make more informed and thus better decisions. $\triangle \mathrm{DIEM}$ is designed to investigate such tough questions and has demonstrated itself to be capable of providing the necessary insights and trends. Future work is planned, in the context of the Bangladesh Delta Plan 2100, to use $\triangle \mathrm{DIEM}$ to evaluate some potential interventions and demonstrate its detailed application to policy.

\section{Appendix 1: Testing and Validating the $\triangle$ DIEM Model}

This appendix reviews the outcomes of the key testing and sensitivity analysis of the Delta Dynamic Integrated Emulator Model ( $\triangle$ DIEM) as follows: (i) uncertainty of the $\triangle \mathrm{DIEM}$ in the emulators, (ii) behaviour 
of the soil salinity calculations compared to observations, (iii) fit to observations and sensitivity of the agriculture model (i.e. the extended CROPWAT model) and (iv) the goodness of fit and sensitivity of the household component model.

\section{Testing of the Emulators}

An emulator statistically represents the input-output relationship of the simulator (i.e. the real, process-based expert model) to achieve an efficient calculation speed that enables a tight-coupled integrative assessment model. Therefore, the accuracy of the emulated results is judged based on the outputs of the simulator model (e.g. inundation depth from the Delft-3D), and thus the emulated accuracy cannot be better than the accuracy of the simulator model.

Emulators' prediction accuracy (compared to the simulator outputs) can be evaluated using several standard metrics. In this research, the rootmean-square error (RMSE) was used. To assess the performance of the emulators, different percentages of available simulation datasets (e.g. Delft-3D outputs) are used to train the emulators (described as the 'training dataset'), and the remaining dataset is used to validate the prediction accuracy. The training dataset is randomly selected and the goodness of fit (i.e. RMSE) is calculated for the remaining dataset that is not used for training. This sampling-predicting-validation process was repeated 30 times to obtain a robust, mean RMSE for each percentage of data used for training.

Table 28.7 summarises the accuracies of the trained emulators compared to the Delft-3D and other model results. Figure 28.13 shows an example for the accuracy test results of the emulators. The magnitude of errors is acceptable for the purposes of the integrated model (i.e. assess trends and cause-effect relationships). Larger scatter occurs for smaller values (e.g. the largest uncertainties are when groundwater salinity $<-0.5 \mathrm{ppt}$ ). From hydrological point of view, the higher values are much more important than the low values (e.g. higher river elevation are the ones that cause flooding) and the emulators are considered adequate. During the normal simulation of $\triangle \mathrm{DIEM}$, the emulators are trained by using all training data, thus having the lowest possible error. 
Table 28.7 Accuracy of the emulators in $\triangle$ DIEM (see also Payo et al. 2017)

\begin{tabular}{|c|c|c|c|}
\hline Emulator & Simulator & $\begin{array}{l}\text { RMSE (min-max): } \\
\text { all randomly } \\
\text { trained } \\
\text { emulators }\end{array}$ & Additional notes \\
\hline $\begin{array}{l}\text { Groundwater } \\
\text { salinity (top and } \\
\text { irrigation layer of } \\
\text { unconfined } \\
\text { aquifer) }\end{array}$ & $\begin{array}{l}\text { Modflow- } \\
\text { Sewat }\end{array}$ & $0.072-0.13 \mathrm{ppt}$ & $\begin{array}{l}\text { Subtle trends at the } \\
\text { beginning of the } \\
\text { simulation period are } \\
\text { not captured well. } \\
\text { Largest uncertainty } \\
\text { when }<\sim 0.5 \text { ppt }\end{array}$ \\
\hline $\begin{array}{l}\text { Depth to } \\
\text { groundwater }\end{array}$ & $\begin{array}{l}\text { Modflow- } \\
\text { Sewat }\end{array}$ & $0.1-0.4 \mathrm{~m}$ & $\begin{array}{l}\text { While the daily variability } \\
\text { is captured by the } \\
\text { emulator, the amplitude } \\
\text { of this variability is } \\
\text { under predicted. Largest } \\
\text { uncertainty when }<1 \mathrm{~m}\end{array}$ \\
\hline River elevation & Delft-3D & $0.35-0.4 \mathrm{~m}$ & $\begin{array}{l}\text { Largest uncertainty when } \\
<2 \mathrm{~m}\end{array}$ \\
\hline Inundation depth & Delft-3D & $0.012-0.13 \mathrm{~m}$ & $\begin{array}{l}\text { Largest uncertainty when } \\
<1 \mathrm{~m}\end{array}$ \\
\hline River salinity & FVCOM & $1.36-2.7 \mathrm{ppt}$ & $\begin{array}{l}\text { Largest uncertainty when } \\
<1 \mathrm{ppt}\end{array}$ \\
\hline
\end{tabular}

\section{Testing of the Soil Salinity Calculations}

The soil salinity calculations of $\triangle D I E M$ are not based on existing expert models, rather a new process-based soil simulation model that is fully coupled in the integrated assessment model is developed (Payo et al. 2017).

Figure 28.14 shows the averaged May 2009 simulated soil salinity of $\triangle \mathrm{DIEM}$ for all three climate scenarios to check the sensitivity of the results to the different climate scenarios. The western Unions are most severely affected by soil salinity under Q0 scenario and less under Q8 scenario. Differences between the three scenarios and the north-east and south-east regions are visually less evident but the summary table of the areal extent (Fig. 28.14) suggests that soil salinity has the minimum effect in the Q8 scenario (i.e. largest nonsaline soil area) and has the maximum effect under the Q0 climate scenario. The extent of soil salinisation is sensitive to the inter-annual variability of the climate, thus can 


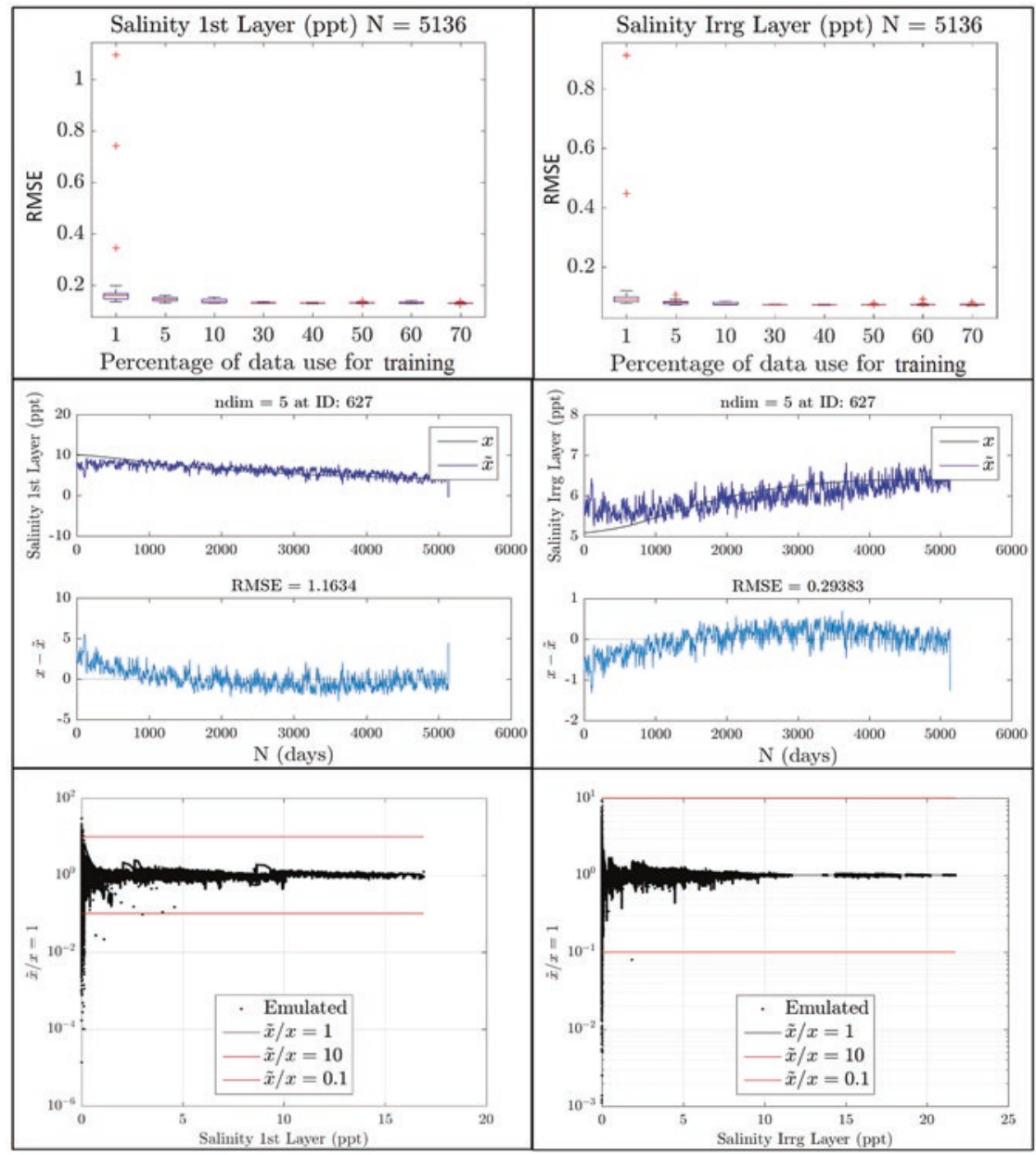

Fig. 28.13 Accuracy of groundwater salinity emulator in $\triangle \mathrm{DIEM}$ at $\sim 10 \mathrm{~m}$ depth (left panels) and 100 m depth (right panels). (RMSE, root-mean-square error; N, sample size; ndim number of principal components used to reduce the dimensionality of the inputs; ID, Union ID; $x$, simulated value; $x$, emulated value; $N$, simulation days)

be significantly different in different years of the simulation. For example, if the period 2001-2009 is used to characterise the monthly mean soil salinity, the total area affected by soil salinity decreases. The non-affected area for the period 2001-2009 is 2.1, 1.6 and 1.5 times larger than the 


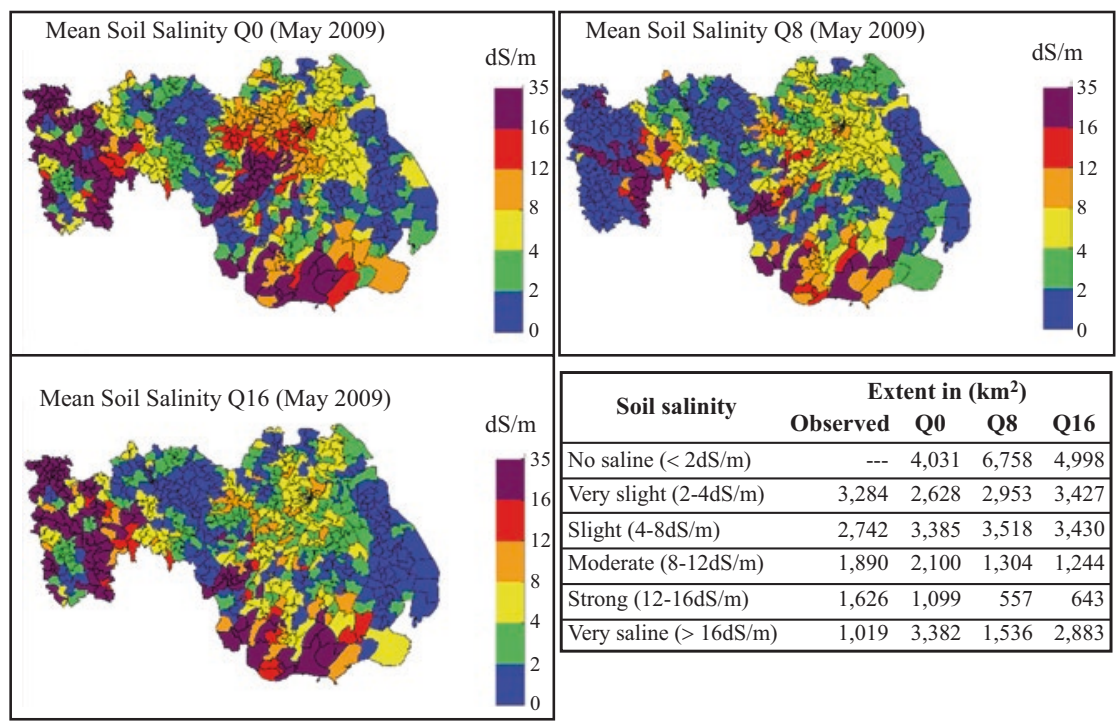

Fig. 28.14 $\triangle$ DIEM soil salinity results for May 2009 (Source of observed area, SRDI (2012))

extent simulated for May 2009 for the scenarios Q0, Q8 and Q16, respectively. An inspection of the reported values at 41 stations by Dasgupta et al. (2014) and the simulated values at Union level suggest that the main spatial variability is well captured for all three scenarios, with Q8 being the closest to the observations (Payo et al. 2017).

Soil salinity is affected by the crops grown on the land through evaporation and irrigation water requirement. $\triangle \mathrm{DIEM}$ simulates soil salinity for each crop within each cropping pattern, and the soil salinity of the broader area is calculated as the area averaged mean. Thus, the model allows comparison of the soil salinity results for each simulated crop. Figure 28.15 contrasts the results with one of the available observations (Mondal et al. 2001) for sesame. Simulated (Q0, Q8, Q16) soil salinity of non-protected areas (i.e. without the protection of an embankment) under sesame farming is in better agreement with observed values than the protected simulations. Unfortunately, the exact location of the experimental field is not known limiting firm conclusions. Furthermore, the Q8 climate scenariodriven simulations produce the best agreement with the observations. 

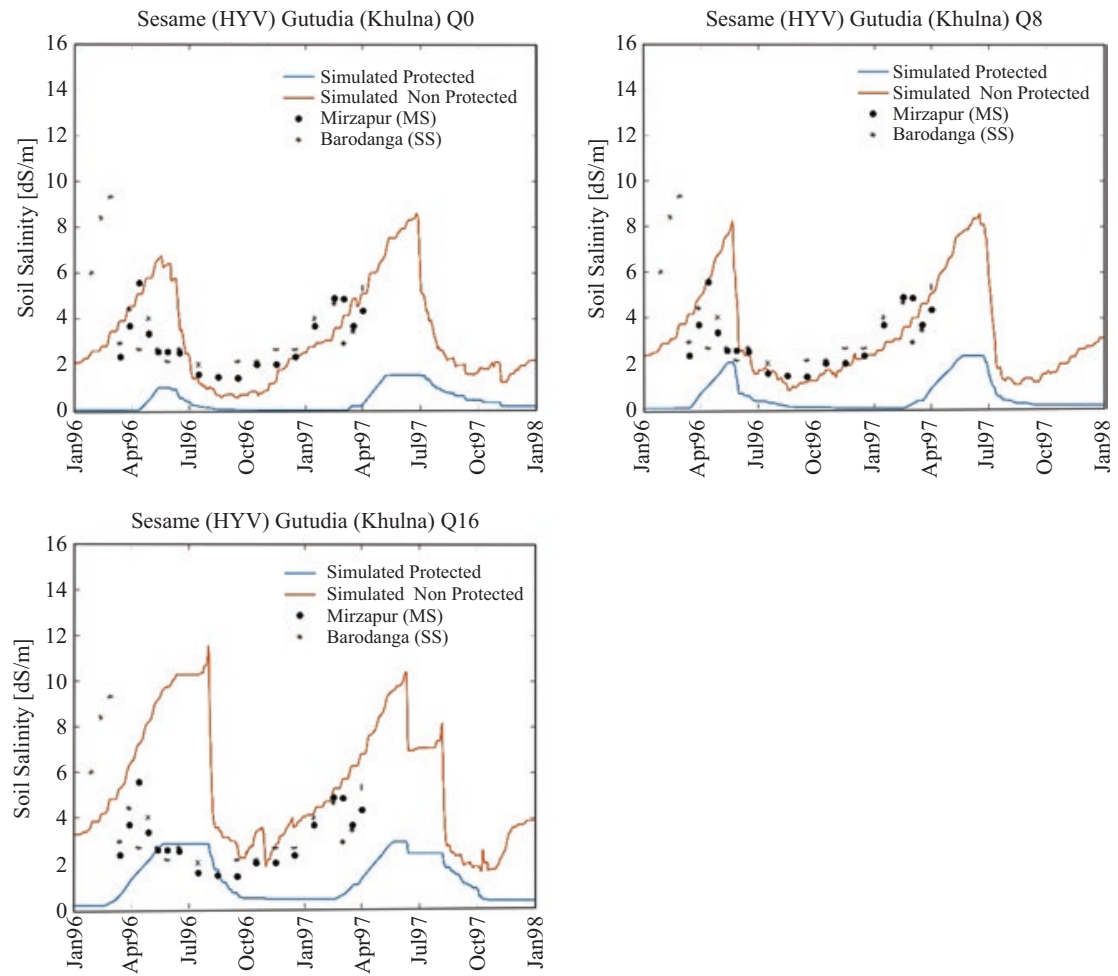

Fig. 28.15 Comparison of Protected and Non-protected simulated soil salinity under Sesame farming with observed values by Mondal et al. (2001) for the Q0, Q8 and Q16 climate scenarios

\section{Testing of the Extended CROPWAT Model}

Similarly to the soil salinity calculations, $\triangle$ DIEM uses its own processbased model to capture the potential of agriculture in the simulations. This section reports the sensitivity and performance of this module.

A preliminary sensitivity analysis revealed that the crop simulations are most sensitive to five out of 23 parameters (Lázár et al. 2015): yield response factor $(\mathrm{Ky})$, the optimum temperature range of maximum growth (Topt and $\mathrm{Topt}_{2}$ ), the crop coefficient of the middle growth period (Kc,mid) and the salinity related yield reduction parameter (Ece,b). The sensitivity of the parameters changes with crops and season. The yield response factor is the single most important variable, resulting in the largest changes in the 
Table 28.8 Crop simulation results of $\triangle$ DIEM at Upazila and district levels (Lázár et al. 2015)

\begin{tabular}{|l|c|c|c|c|c|c|}
\hline & \multicolumn{7}{|c|}{ Goodness-of-fit results } \\
\hline \hline \multicolumn{1}{|c|}{ Crops } & $\begin{array}{c}\text { RMSE (2000, } \\
\text { Upazila, \%) }\end{array}$ & $\begin{array}{c}\text { RMSE (2005, } \\
\text { Upazila, \%) }\end{array}$ & $\begin{array}{c}\text { RMSE (2010, } \\
\text { Upazila, \%) }\end{array}$ & $\begin{array}{c}\text { RMSE (1990, } \\
\text { district, \%) }\end{array}$ & $\begin{array}{c}\text { RMSE (2000, } \\
\text { district, \%) }\end{array}$ & $\begin{array}{c}\text { RMSE (2010, } \\
\text { district, \%) }\end{array}$ \\
\hline \hline T. Aman (local) & 14.1 & 9.7 & 4.1 & 8.2 & & 2.3 \\
\hline T Aman (HYV) & 8.8 & 8.8 & 8.6 & 60.3 & 28.1 & 6.9 \\
\hline T.Aus (local) & 38.8 & 5.2 & 5.9 & 6.8 & & 2.7 \\
\hline T Aus (HYV) & 16.0 & 18.3 & 10.1 & 47.4 & 17.9 & 9.6 \\
\hline Boro (HYV) & 8.7 & 12.0 & 11.0 & 50.3 & 13.6 & 11.9 \\
\hline \hline Chilli (local, rabi) & & & & 15.4 & & 8.4 \\
\hline Chilli (hybrid, rabi) & 18.7 & 14.4 & 10.4 & 58.3 & 32.9 & 7.4 \\
\hline Grass pea (HYV) & 48 & 26 & 29 & 123 & 44 & 24 \\
\hline Potato (HYV) & 76 & 49 & 65 & 315 & 207 & 70 \\
\hline Wheat (HYV) & 28.4 & 28.8 & 24.6 & 144.1 & 99.8 & 22.0 \\
\hline
\end{tabular}

Notes: green, very good agreement ( $<15$ per cent); blue, acceptable agreement (15-30 per cent); orange, fair agreement (30-50 per cent); red, poor agreement ( $>50$ per cent); white cells, no observation

results (up to 55 per cent difference compared to the baseline results). The four other parameters have smaller but still significant impact resulting in a 15-35 per cent difference in the outputs.

Observations on crop productivity were available from the Department of Agricultural Extension (DAE) at Upazila and district levels. The calibrated crop parameters resulted in a good fit in most cases for 2010 at both levels (Table 28.8). Representation of the year 2000 conditions was mostly acceptable, but district-level simulation results for the year 1990 almost always greatly deviated from the district-level observations. Conversely, the Upazila-level simulations showed good correlation with the observations for 2000, 2005 and 2010. The deviation from the observed values for 1990 due to a mixture of four issues:

1. Model structural error and parameter uncertainty

2. Uncertainty around the observed farmers' yield

(a) The way it was collected and entered into databases might have changed over time.

(b) Data for different varieties are mixed up in one average yield value (e.g. T.Aus HYV), and the proportion of these varieties in the statistics has changed over time. 
3. The management of the crops could have drastically improved since 1990, but the CROPWAT model does not any include managementrelated equations/parameters apart from irrigation.

4. Soil salinity is highly spatially and temporally variable in the coastal zone of Bangladesh, and observed, homogenous soil salinity time series are not available. The present study used average Upazila-level, yearly salinity values for 1971, 2000 and 2009 and carried out a linear interpolation in between the observed values. Finally, the seasonality of soil salinity was assumed to be the same as for river salinity. This approach holds considerable uncertainties for the model results.

The Upazila-level simulated yields are generally representing the observations well. The fit to observations was not so good for some minor crops, such as potato and grass pea, but they are generally accounted for less than ten per cent of the total agriculture area in coastal Bangladesh. The recalibration of these crops would require further data that is currently not available.

\section{Testing of the Process-Based Socio-economic Component}

The $\triangle \mathrm{DIEM}$ uses its own simple agent-based-type model to capture the behaviour and monetary well-being of the coastal population. Validation of socio-economic results is very difficult, because monthly observations for millions of people with such detail are not available. However, national survey results are accessible for comparison with $\triangle \mathrm{DIEM}$ aggregated results; the summary statistics of the HIES surveys (BBS 2011) for five variables (Fig. 28.16) were used. Mean total household expenditure matches well the observations, both in terms of trend and magnitude. However, the range (grey area) shows calculated values from almost nothing to significant amounts. Calculated mean calorie- and protein-intake values agree well with the rural-specific observations. In the same way as the total household expenditure, these figures also show that for some households the food intake is at very low levels (food poverty line of Bangladesh is 2,122 kcal/capita/day; BBS (2011), page 59). The GINI coefficient measures the income inequality of the population. 


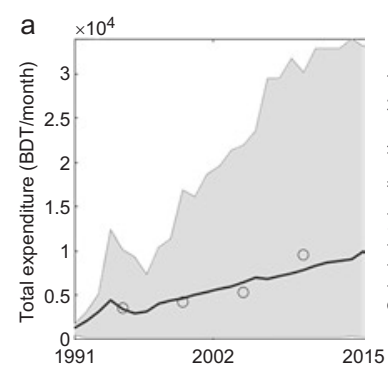

d

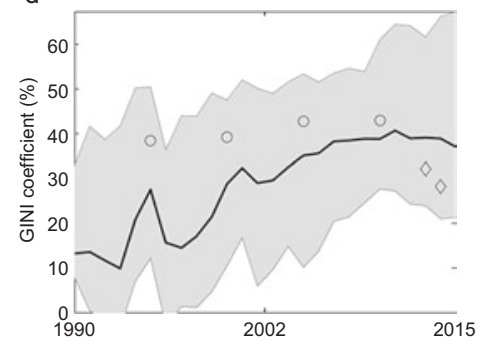

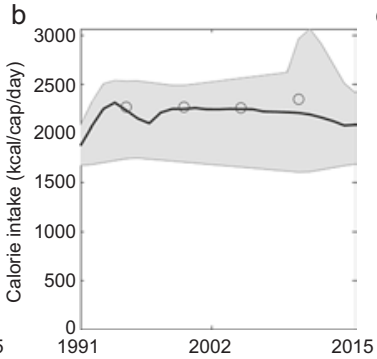
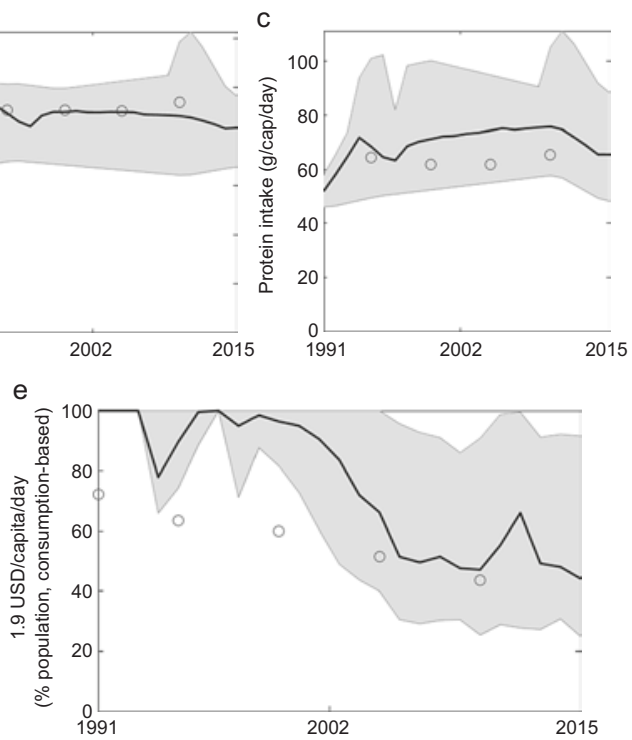

Fig. 28.16 Validation of the process-based household component of $\triangle$ DIEM. Black lines show the simulated mean study area values, shaded area shows the min-max simulated range within the study area, and grey dots and diamonds are observations. Observations: (a) BBS (2011) Table 4.4; (b) BBS (2011) Table 5.3; (c) BBS (2011) Table 5.4; (d) dots: rural inequality (Ferdousi and Dehai (2014)), diamonds: national inequality (UNDP (http://hdr.undp.org/en/content/income-gini-coefficient accessed on 08/07/2016)); (e) World Bank: People living on less than $\$ 1.90$ a day (http:// povertydata.worldbank.org/poverty/country/BGD accessed on 08/07/2016)

The larger the inequality index, the larger the income difference between the poorest and richest households. The calculated mean inequality is lower than the observed, meaning that most of the population have more similar income levels. The model trend is increasing inequality over time, and the calculated value reaches the observed level by 2010 , beyond which the inequality stabilises and decreases slightly. $\triangle D I E M$ results are closer to the rural observations than the national average. Finally, the World Banks's national 'People living on less than $\$ 1.90 \mathrm{a}$ day' indicator is also used to assess the calculated results. To calculate this, household consumption is used, as opposed to household income, 
because consumption can be more reliably measured. The calculated total household consumption levels are adjusted with the World Bank's purchase power parity (PPP) conversion factor. In the 1990s, this calculated headcount indicator is hugely overestimated compared to the 'observed' national average. All households are below this $\$ 1.90$ poverty threshold. As the simulation progresses, however, the poverty prevalence decreases substantially and, by 2005 , it reaches the magnitude of the observations. This model behaviour can be attributed partially to the uncertainty of the input data for $\triangle \mathrm{DIEM}$ and partially that the model needs a few years at the beginning of the simulation before an equilibrium of the simulated household finances is reached. Overall, the model behaves as expected and reproduces the national trends well.

A sensitivity analysis, similar methodology to the CROPWAT study, investigated the importance of all 17 model parameters of the processbased household component. This exercise only uses observations (BBS 2011 and the ESPA household survey dataset) and does not use any inputs from the full $\triangle \mathrm{DIEM}$ model to avoid introducing additional errors. Five model parameters showed no sensitivity (Fig. 28.17; initial cash savings, initial asset savings, loan grace period, minimum saved income and coping strategies). Therefore, they could be excluded from the model if a more rigorous analysis also finds them insensitive. When the mean sensitivity is assessed, it is clear that only the 'target affordability', 'official loan APR' (i.e. annual percentage rate charged for borrowing) and 'waiting time to increase expenditure level' are the important parameters. However, when the minimum-maximum range of sensitivity is assessed, a few parameters are very important for all household archetypes: 'target affordability', 'APR of official loans', 'waiting time to increase expenditure level', 'savings that cannot be spent', and 'income drop' (i.e. how much the income is reduced if not all the livelihood costs are paid). Other parameters have moderate or no sensitivity depending on the household type in question. The most sensitive household types are landless or small land owners with lower income levels who try to balance farm-related activities with other off-farm occupations. 

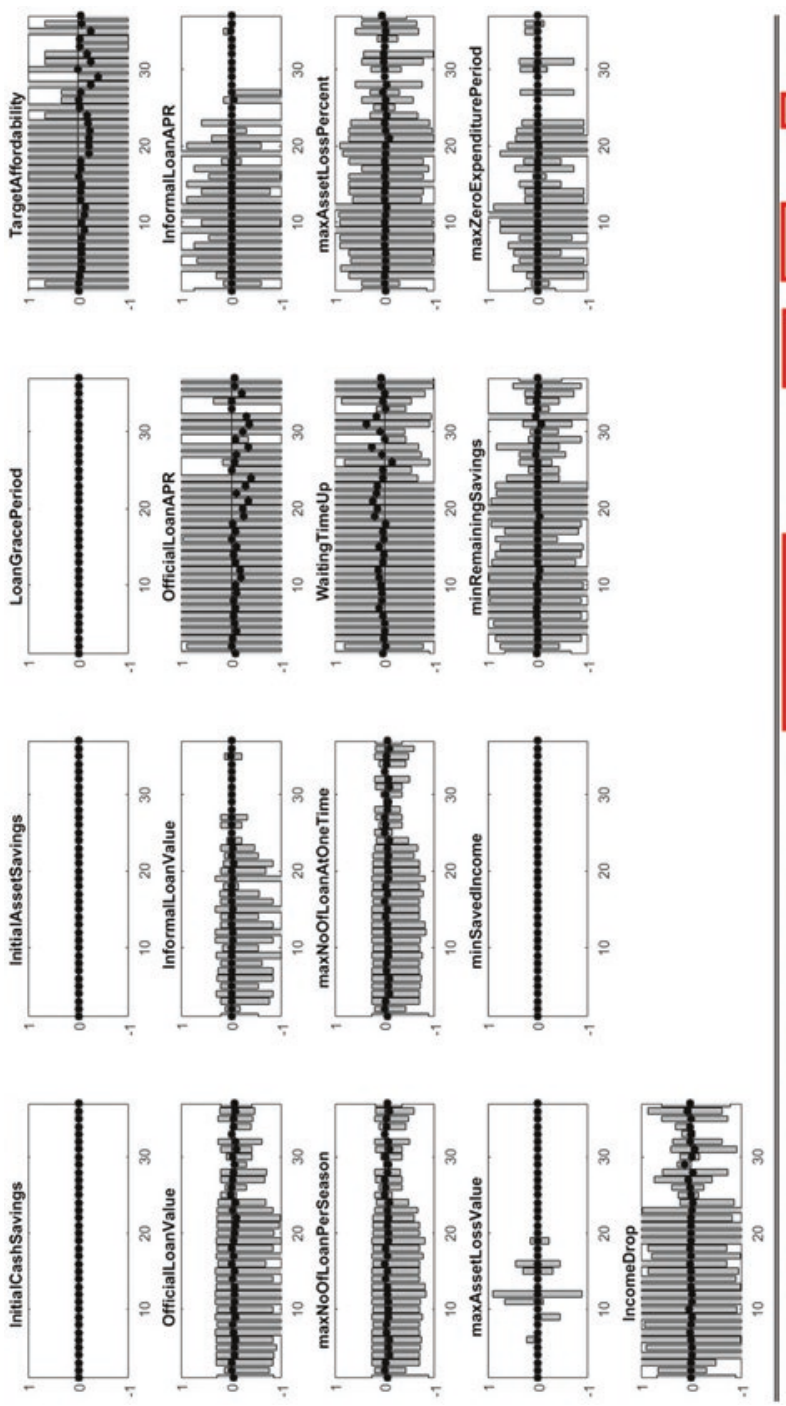

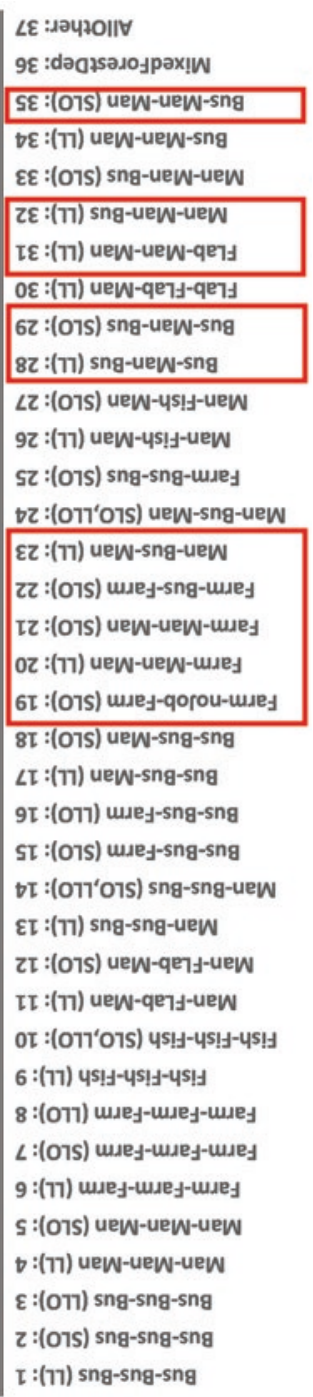




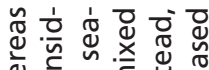

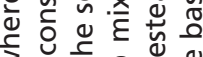

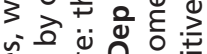

ขิ

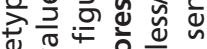

눈 능 훙

ปั ह

을 율

जे

응 월

은 岳 $\bar{x}$

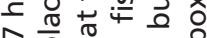

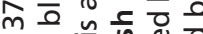

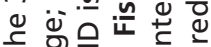

음

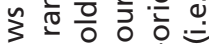

을 을 엉

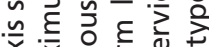

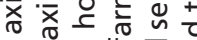

$x$ ह 두 ᄂ $\overline{0}$

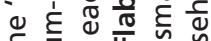

施

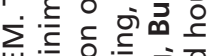

Ш ह 흐 잉

닌은 는

을 ฮ

닌

흐는 등

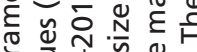

군.

음 윰든

व

ह :

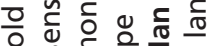

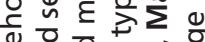

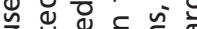

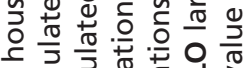

Ч ह ฉ

$0 \cdot \frac{1}{n} \cdot \frac{2}{3}$ 을

文过记式㐫

$>$ ᄃ

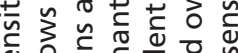

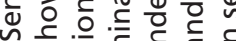

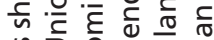

듬ำ

$\infty-\pi \geq 0$

N $>$ वे

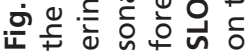




\section{References}

BBS. 2011. Report of the household income and expenditure survey 2010. Dhaka: Bangladesh Bureau of Statistics (BBS).

Dasgupta, S., M. Hossain, M. Huq, and D. Wheeler. 2014. Climate change, soil salinity, and the economics of high-yield riceproduction in coastal Bangladesh. Policy Research Working Paper 7140. Washington, DC: Environment and EnergyTeam, Development Research Group, World Bank. http://documents.worldbank.org/curated/en/131161468004833954/pdf/WPS7140. pdf. Accessed 9 Aug 2016.

Ferdousi, S., and W. Dehai. 2014. Economic growth, poverty and inequality trend in Bangladeah. Asian Journal of Social Sciences and Humanities 3 (1): $1-11$.

Lázár, A.N., D. Clarke, H. Adams, A.R. Akanda, S. Szabo, R.J. Nicholls, Z. Matthews, D. Begum, A.F.M. Saleh, M.A. Abedin, A. Payo, P.K. Streatfield, C. Hutton, M.S. Mondal, and A.Z.M. Moslehuddin. 2015. Agricultural livelihoods in coastal Bangladesh under climate and environmental change A model framework. Environmental Science-Processes and Impacts 17 (6):1018-1031. https://doi.org/10.1039/c4em00600c.

Mondal, M.K., S.I. Bhuiyan, and D.T. Franco. 2001. Soil salinity reduction and prediction of salt dynamics in the coastal ricelands of Bangladesh. Agricultural Water Management 47 (1): 9-23. https://doi.org/10.1016/ s0378-3774(00)00098-6.

Payo, A., A.N. Lázár, D. Clarke, R.J. Nicholls, L. Bricheno, S. Mashfiqus, and A. Haque. 2017. Modeling daily soil salinity dynamics in response to agricultural and environmental changes in coastal Bangladesh. Earth's Future. https://doi.org/10.1002/2016EF000530.

SRDI. 2012. Analytical methods: Soil, water, plant material and fertilizer. 2nd ed. Dhaka: Soil Resource Development Institute (SRDI), Ministry of Agriculture, Government of the People's Republic of Bangladesh. 


\section{Appendix 2: $\triangle$ DIEM Model Scenario Inputs}

Summary tables of indicator changes within each $\triangle \mathrm{DIEM}$ forcing scenario. Climate change scenarios Q0, Q8, Q16 (see Chap. 11) and socioeconomic scenarios LS (Less Sustainable), BAU (Business As Usual), MS (More Sustainable) (see Appendix to Chap. 10 for scenario narratives).

\begin{tabular}{|c|c|c|c|c|c|c|}
\hline \multirow{2}{*}{\multicolumn{2}{|c|}{$\begin{array}{c}\text { Indicator Units } \\
\text { Temperature }\end{array}$}} & \multirow[t]{2}{*}{ Scenario } & \multicolumn{3}{|c|}{ Changes from 2015} & \multirow[t]{5}{*}{ Notes } \\
\hline & & & 2050 & 2098 & & \\
\hline \multirow{3}{*}{$\begin{array}{l}\text { Average } \\
\text { temperature } \\
\text { maximum }\end{array}$} & \multirow[t]{3}{*}{${ }^{\circ} \mathrm{C}$} & Q0 & 2.4 & \multicolumn{2}{|l|}{3.7} & \\
\hline & & Q8 & 2.5 & \multicolumn{2}{|l|}{3.7} & \\
\hline & & Q16 & 2.8 & \multicolumn{2}{|l|}{4.1} & \\
\hline \multirow{2}{*}{\multicolumn{2}{|c|}{$\begin{array}{c}\text { Indicator Units } \\
\text { Sea level }\end{array}$}} & Scenario & \multicolumn{3}{|c|}{ Changes from 2000} & Notes \\
\hline & & & 2030 & 2050 & 2098 & \\
\hline \multirow[t]{2}{*}{ Sea level } & $\mathrm{Cm}$ & Low & 12 & 24 & 54 & \multirow{2}{*}{$\begin{array}{l}\text { Subsidence: } \\
2.5 \mathrm{~mm} / \text { year } \\
\text { (reference to } \\
\text { year 2000) }\end{array}$} \\
\hline & & High & 20 & 45 & 148 & \\
\hline \multirow{2}{*}{$\begin{array}{l}\text { Indicator Water } \\
\text { Wal }\end{array}$} & Units & Scenario & \multicolumn{3}{|c|}{ Changes from 2015} & Notes \\
\hline & & & 2030 & 2050 & 2098 & \\
\hline \multirow{3}{*}{$\begin{array}{l}\text { Total } \\
\text { monsoon } \\
\text { season } \\
\text { rainfall } \\
\text { (June-Sep.) }\end{array}$} & $\%$ & Q0 & 2 & 5 & 0 & \multirow{15}{*}{$\begin{array}{l}\text { Dry } \\
\text { day =precipita- } \\
\text { tion below } \\
1 \mathrm{~mm}\end{array}$} \\
\hline & & Q8 & -17 & -21 & -9 & \\
\hline & & Q16 & 3 & -4 & 14 & \\
\hline \multirow{3}{*}{$\begin{array}{l}\text { Total dry } \\
\text { season } \\
\text { rainfall } \\
\text { (Dec.-Feb.) }\end{array}$} & $\%$ & Q0 & -37 & 25 & 0 & \\
\hline & & Q8 & -57 & -56 & -38 & \\
\hline & & Q16 & 30 & -3 & 29 & \\
\hline \multirow{3}{*}{$\begin{array}{l}\text { Total number } \\
\text { of dry days } \\
\text { per year }\end{array}$} & $\%$ & Q0 & 1 & -2 & -1 & \\
\hline & & Q8 & 8 & 5 & 6 & \\
\hline & & Q16 & -1 & 1 & 0 & \\
\hline \multirow{3}{*}{$\begin{array}{l}\text { Length of } \\
\text { longest } \\
\text { consecutive } \\
\text { dry day } \\
\text { period }\end{array}$} & $\%$ & Q0 & -23 & -24 & -1 & \\
\hline & & Q8 & -4 & -3 & 28 & \\
\hline & & Q16 & 7 & 20 & 1 & \\
\hline \multirow{3}{*}{$\begin{array}{l}\text { Total annual } \\
\text { rainfall }\end{array}$} & $\%$ & Q0 & 6 & 10 & 11 & \\
\hline & & Q8 & -23 & -21 & -13 & \\
\hline & & Q16 & 2 & -3 & 14 & \\
\hline
\end{tabular}


(continued)

\begin{tabular}{|c|c|c|c|c|c|c|}
\hline \multirow{2}{*}{$\begin{array}{l}\text { Indicator } \\
\text { Water }\end{array}$} & \multirow{2}{*}{ Units } & \multirow{2}{*}{ Scenario } & \multicolumn{3}{|c|}{ Changes from 2015} & \multirow{2}{*}{ Notes } \\
\hline & & & 2030 & 2050 & 2098 & \\
\hline \multirow{3}{*}{$\begin{array}{l}\text { Ganges } \\
\text { annual } \\
\text { maximum } \\
\text { discharge }\end{array}$} & \multirow[t]{3}{*}{$\%$} & Q0 & 5 & 10 & 19 & \\
\hline & & Q8 & 13 & 18 & 31 & \\
\hline & & Q16 & 24 & 35 & 67 & \\
\hline \multirow{3}{*}{$\begin{array}{l}\text { Brahmaputra } \\
\text { annual } \\
\text { maximum } \\
\text { discharge }\end{array}$} & \multirow[t]{3}{*}{$\%$} & Q0 & 5 & 13 & 17 & \\
\hline & & Q8 & 3 & -5 & 2 & \\
\hline & & Q16 & 12 & 39 & 82 & \\
\hline \multirow{3}{*}{$\begin{array}{l}\text { Meghna } \\
\text { annual } \\
\text { maximum } \\
\text { discharge }\end{array}$} & \multirow[t]{3}{*}{$\%$} & Q0 & 7 & 11 & 20 & \\
\hline & & Q8 & 11 & 17 & 31 & \\
\hline & & Q16 & 25 & 33 & 64 & \\
\hline \multirow[t]{3}{*}{ Water sharing } & \multirow{3}{*}{$\begin{array}{l}\text { Farraka } \\
\text { treaty } \\
\text { arrange- } \\
\text { ments }\end{array}$} & LS & \multirow{3}{*}{\multicolumn{3}{|c|}{$\begin{array}{l}\text { Constant: } 30,000 \text { cfs guaranteed } \\
\text { Constant: } 35,000 \text { cfs guaranteed } \\
\text { Constant: } 40,000 \text { cfs guaranteed }\end{array}$}} & \\
\hline & & BAU & & & & \\
\hline & & MS & & & & \\
\hline \multirow{3}{*}{$\begin{array}{l}\text { Water } \\
\text { transfers }\end{array}$} & \multirow{3}{*}{$\begin{array}{l}\% \text { flow } \\
\text { reduction }\end{array}$} & \multicolumn{4}{|l|}{ No change } & \\
\hline & & \multicolumn{3}{|c|}{$\begin{array}{c}\text { Small transfer ( } 5 \% \text { of } \\
\text { Brahmaputra flow) }\end{array}$} & Negligible & \\
\hline & & \multicolumn{3}{|c|}{$\begin{array}{l}\text { Large transfer ( } 20 \% \text { of } \\
\text { Ganges, } 30 \% \text { of } \\
\text { Brahmaputra flow) }\end{array}$} & $\begin{array}{l}22 \text { (monsoon), } \\
48 \text { (dry } \\
\text { season) }\end{array}$ & \\
\hline $\begin{array}{l}\text { Cyclone } \\
\text { frequency }\end{array}$ & Per year & \multicolumn{5}{|c|}{ Set manually using illustrative cyclones } \\
\hline
\end{tabular}

\begin{tabular}{|c|c|c|c|c|c|c|}
\hline \multirow[t]{2}{*}{ Indicator } & \multirow[b]{2}{*}{ frastructure } & \multirow{2}{*}{ Scenario } & \multicolumn{3}{|c|}{ Changes from 2015} & \multirow[t]{3}{*}{ Notes } \\
\hline & & & 2030 & 2050 & 2098 & \\
\hline $\begin{array}{l}\text { Embankment } \\
\text { height }\end{array}$ & Metres & $\begin{array}{l}\text { All } \\
\text { scenarios }\end{array}$ & \multicolumn{3}{|c|}{ Unchanged from design height } & \\
\hline \multirow{3}{*}{$\begin{array}{l}\text { Travel time to } \\
\text { main } \\
\text { settlements }\end{array}$} & \multirow[t]{3}{*}{$\%$} & LS & -10 & -10 & -10 & \\
\hline & & BAU & -30 & -30 & -30 & \\
\hline & & MS & -50 & -50 & -50 & \\
\hline \multirow{2}{*}{\multicolumn{2}{|c|}{$\begin{array}{c}\text { Indicator Units } \\
\text { Land use }\end{array}$}} & Scenario & \multicolumn{3}{|c|}{ Changes with 2015} & Notes \\
\hline & & & 2050 & 2098 & & \\
\hline \multirow{3}{*}{$\begin{array}{l}\text { Agricultural } \\
\text { land cover }\end{array}$} & \multirow[t]{3}{*}{$\%$} & LS & -8 & -26 & & \\
\hline & & BAU & 3 & 7 & & \\
\hline & & MS & -3 & -3 & & \\
\hline \multirow{3}{*}{$\begin{array}{l}\text { Urban land } \\
\text { cover }\end{array}$} & \multirow[t]{3}{*}{$\%$} & LS & \multirow{2}{*}{\multicolumn{3}{|c|}{$\begin{array}{l}\text { No change } \\
\text { No change }\end{array}$}} & \\
\hline & & BAU & & & & \\
\hline & & MS & 92 & 92 & & \\
\hline \multirow{3}{*}{$\begin{array}{l}\text { Rural } \\
\text { settlement } \\
\text { land cover }\end{array}$} & \multirow[t]{3}{*}{$\%$} & LS & \multirow{2}{*}{\multicolumn{3}{|c|}{$\begin{array}{l}\text { No change } \\
\text { No change }\end{array}$}} & \\
\hline & & BAU & & & & \\
\hline & & MS & -1 & -1 & & \\
\hline
\end{tabular}


(continued)

\begin{tabular}{|c|c|c|c|c|c|c|}
\hline \multirow{2}{*}{$\begin{array}{l}\text { Indicator } \\
\qquad \text { Land us }\end{array}$} & \multirow{2}{*}{$\begin{array}{l}\text { Units } \\
\text { se }\end{array}$} & \multirow[t]{2}{*}{ Scenario } & \multicolumn{3}{|c|}{ Changes with 2015} & \multirow[t]{2}{*}{ Notes } \\
\hline & & & 2050 & 2098 & & \\
\hline \multirow{3}{*}{$\begin{array}{l}\text { Mangrove } \\
\text { land cover } \\
\text { within the } \\
\text { Unions }\end{array}$} & \multirow{3}{*}{$\%$} & LS & -10 & \multicolumn{2}{|l|}{-19} & \\
\hline & & BAU & -5 & \multicolumn{2}{|l|}{-15} & \\
\hline & & MS & 92 & \multicolumn{2}{|l|}{92} & \\
\hline \multirow{3}{*}{ Crops grown } & \multirow{3}{*}{ Crop name } & IS & \multicolumn{3}{|c|}{ 1990s crops } & \\
\hline & & BAU & \multicolumn{3}{|c|}{ Present day crops } & \\
\hline & & MS & \multicolumn{3}{|c|}{ Present day crops } & \\
\hline \multirow[t]{3}{*}{ Crop varieties } & \multirow{3}{*}{$\begin{array}{l}\% \text { yield } \\
\text { improve- } \\
\text { ment }\end{array}$} & LS & \multicolumn{3}{|c|}{ Present day (0) } & \\
\hline & & BAU & \multicolumn{2}{|c|}{$\begin{array}{l}\text { Present } 15 \\
\text { day } \\
(0)\end{array}$} & & \\
\hline & & MS & 15 & \multicolumn{2}{|l|}{50} & \\
\hline \multirow{2}{*}{\multicolumn{2}{|c|}{$\begin{array}{l}\text { Indicator Units } \\
\text { Socioeconomics }\end{array}$}} & Scenario & \multicolumn{3}{|c|}{ Changes from 2015} & Notes \\
\hline & & & 2030 & 2050 & 2098 & \\
\hline \multirow[t]{3}{*}{ Population } & \multirow[t]{3}{*}{$\%$} & LS & 1.1 & -0.7 & -25.1 & \\
\hline & & BAU & 0.5 & -7.7 & -32.9 & \\
\hline & & MS & -3.8 & -7.2 & -36.7 & \\
\hline \multirow[t]{3}{*}{ Literacy rate } & \multirow[t]{3}{*}{$\%$} & LS & 2 & 2 & 2 & \\
\hline & & BAU & 4 & 4 & 4 & \\
\hline & & MS & 8 & 8 & 8 & \\
\hline \multirow{3}{*}{$\begin{array}{l}\text { Children in } \\
\text { school }\end{array}$} & \multirow[t]{3}{*}{$\%$} & LS & 2 & 2 & 2 & \\
\hline & & BAU & 5 & 5 & 5 & \\
\hline & & MS & 10 & 10 & 10 & \\
\hline \multirow{3}{*}{$\begin{array}{l}\text { Employment } \\
\text { rate }\end{array}$} & \multirow[t]{3}{*}{$\%$} & LS & 0 & 0 & 0 & \\
\hline & & BAU & 10 & 10 & 10 & \\
\hline & & MS & 30 & 30 & 30 & \\
\hline Total & $\%$ & LS & 3 & 6 & 6.5 & \\
\hline migration & & BAU & 2.2 & 4.8 & 6 & \\
\hline & & MS & 3 & 5 & 5 & \\
\hline Migration & $\%$ & LS & 0 & -50 & -100 & No further \\
\hline rate & & BAU & -37 & -37 & -100 & $\begin{array}{l}\text { migration } \\
\text { assumed } \\
\text { beyond } 2050\end{array}$ \\
\hline & & MS & -25 & -75 & -100 & \\
\hline Food variety & Kcal/day & $\begin{array}{l}\text { All } \\
\text { scenarios }\end{array}$ & $\begin{array}{r}\text { Uncha } \\
48-8\end{array}$ & $\begin{array}{l}\text { ed }(17 \\
\text { protein }\end{array}$ & 2422 with & \\
\hline
\end{tabular}




\section{References}

Amoako Johnson, F., C.W. Hutton, D. Hornby, A.N. Lázár, and A. Mukhopadhyay. 2016. Is shrimp farming a successful adaptation to salinity intrusion? A geospatial associative analysis of poverty in the populous Ganges-Brahmaputra-Meghna Delta of Bangladesh. Sustainability Science 11 (3): 423-439. https://doi.org/10.1007/s11625-016-0356-6.

BARC. 2013. Agricultural technology for Southern Region of Bangladesh (in Bangla). Dhaka: Bangladesh Agricultural Research Council (BARC). https:// archive.org/details/AgriculturalTechnologySouthernRegion. Accessed 26 Oct 2016.

Caesar, J., T. Janes, A. Lindsay, and B. Bhaskaran. 2015. Temperature and precipitation projections over Bangladesh and the upstream Ganges, Brahmaputra and Meghna systems. Environmental Science-Processes and Impacts 17 (6): 1047-1056. https://doi.org/10.1039/c4em00650j.

Clark, D. 1975. Understanding canonical correlation analysis, Concepts and techniques in modern geography No. 3. Norwich: Geo Abstracts Ltd.

Clarke, D., M. Smith, and K. El-Askari. 1998. New software for crop water requirements and irrigation scheduling. Irrigation and Drainage 47 (2): 45-58.

Clarke, D., S. Williams, M. Jahiruddin, K. Parks, and M. Salehin. 2015. Projections of on-farm salinity in coastal Bangladesh. Environmental Science-Processes and Impacts 17 (6): 1127-1136. https://doi.org/10.1039/ c4em00682h.

FAO, and MA. 2013. Master plan for agricultural development in the Southern Region of Bangladesh. Food and Agriculture Organization of the United Nations (FAO) and Government of the People's Republic of Bangladesh, Ministry of Agriculture (MA).

Farakka Treaty. 1996. Treaty between the Government of the People's Republic of Bangladesh and the Government of the Republic of India on sharing of the Ganga/Ganges water at Farakka. 36 I.L.M 523 (1997).

Fernandes, J.A., S. Kay, M.A.R. Hossain, M. Ahmed, W.W.L. Cheung, A.N. Lázár, and M. Barange. 2016. Projecting marine fish production and catch potential in Bangladesh in the 21st century under long-term environmental change and management scenarios. ICES Journal of Marine Science 73 (5): 1357-1369. https://doi.org/10.1093/icesjms/fsv217. 
Kay, S., J. Caesar, J. Wolf, L. Bricheno, R.J. Nicholls, A.K.M.S. Islam, A. Haque, A. Pardaens, and J.A. Lowe. 2015. Modelling the increased frequency of extreme sea levels in the Ganges-Brahmaputra-Meghna delta due to sea level rise and other effects of climate change. Environmental Science-Processes and Impacts 17 (7): 1311-1322. https://doi.org/10.1039/c4em00683f.

Lázár, A.N., D. Clarke, H. Adams, A.R. Akanda, S. Szabo, R.J. Nicholls, Z. Matthews, D. Begum, A.F.M. Saleh, M.A. Abedin, A. Payo, P.K. Streatfield, C. Hutton, M.S. Mondal, and A.Z.M. Moslehuddin. 2015. Agricultural livelihoods in coastal Bangladesh under climate and environmental change A model framework. Environmental Science-Processes and Impacts 17 (6): 1018-1031. https://doi.org/10.1039/c4em00600c.

Lázár, A.N., H. Adams, W.N. Adger, and R.J. Nicholls. 2016. Characterising and modelling households in coastal Bangladesh for model development. Project working paper. ESPA Deltas.

MathWorks. 2015. MATLAB and statistics toolbox release 2015b. Natick: The MathWorks, Inc.

Oreskes, N., K. Shraderfrechette, and K. Belitz. 1994. Verification, validation and confirmation on numerical-models in the earth sciences. Science 263 (5147): 641-646. https://doi.org/10.1126/science.263.5147.641.

Payo, A., A.N. Lázár, D. Clarke, R.J. Nicholls, L. Bricheno, S. Mashfiqus, and A. Haque. 2017. Modeling daily soil salinity dynamics in response to agricultural and environmental changes in coastal Bangladesh. Earth's Future. https://doi.org/10.1002/2016EF000530.

Szabo, S., D. Begum, S. Ahmad, Z. Matthews, and P.K. Streatfield. 2015. Scenarios of population change in the coastal Ganges Brahmaputra Delta (2011-2051). Asia Pacific Population Journal 30 (2): 51-72.

Whitehead, P.G., E. Barbour, M.N. Futter, S. Sarkar, H. Rodda, J. Caesar, D. Butterfield, L. Jin, R. Sinha, R. Nicholls, and M. Salehin. 2015. Impacts of climate change and socio-economic scenarios on flow and water quality of the Ganges, Brahmaputra and Meghna (GBM) river systems: Low flow and flood statistics. Environmental Science-Processes and Impacts 17 (6): 10571069. https://doi.org/10.1039/c4em00619d. 
Open Access This chapter is licensed under the terms of the Creative Commons Attribution 4.0 International License (http://creativecommons.org/licenses/ by/4.0/), which permits use, sharing, adaptation, distribution and reproduction in any medium or format, as long as you give appropriate credit to the original author(s) and the source, provide a link to the Creative Commons license and indicate if changes were made.

The images or other third party material in this chapter are included in the chapter's Creative Commons license, unless indicated otherwise in a credit line to the material. If material is not included in the chapter's Creative Commons license and your intended use is not permitted by statutory regulation or exceeds the permitted use, you will need to obtain permission directly from the copyright holder.

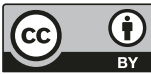

